\title{
BERTOLT BRECHT V SLOVENSKOM DIVADLE V ROKOCH 1975 - 1985
}

\author{
ELENA KNOPOVÁ
}

Ústav divadelnej a filmovej vedy Centra vied o umení Slovenskej akadémie vied, Bratislava

\begin{abstract}
Abstrakt: Štúdia sa zameriava na inscenácie hier Bertolta Brechta v slovenskom divadle v rokoch 1975 - 1985. Časovo nadväzuje na staršiu štúdiu Martina Porubjaka (1975), ktorý sa venoval obdobiu rokov 1947 - 1974, a spracúva d’alšie desatročie inscenačnej tradície Brechtových hier na Slovensku. Autorka v úvode približuje Brechtove názory a požiadavky kladené na epické divadlo, ponúka základný pohl'ad na jeho estetiku a poetiku (dialektického) divadla a drámy. Pozornost' upriamuje najmä na vzt’ah divadla a spoločnosti, ktorý by mal byt' pre divadelné spracovanie Brechtových hier kl’účový. Jednotlivé inscenácie slovenských tvorcov následne v chronologickom slede rekonštruuje na základe dochovaných archívnych materiálov, posudzuje a porovnáva ich s Brechtovou víziou revolučného divadla sociálnej zmeny (účinku), zohl'adňujúc domáci umelecký, ale aj spoločenský kontext.
\end{abstract}

Kl'účové slová: Bertolt Brecht, epické divadlo, slovenské divadlo, angažované politické divadlo

Bertolt Brecht patrí $\mathrm{k}$ dramatikom, režisérom, dramaturgom a teoretizujúcim praktikom, ktorí výrazne ovplyvnili európske divadlo 20. storočia. V zmysle „divadla vlastnej epochy", o ktoré sa usiloval, boli s rôznym úspechom inscenované a interpretované aj jeho hry. Werner Hecht, divadelný vedec a dramaturg Berliner Ensamble, ktorý dôverne poznal Brechtovu prácu, ${ }^{1}$ zastával názor, že osvojit’ si Brechta znamená postupovat pri uplatňovaní jeho metódy a interpretácii jeho hier neortodoxne. To znamená, prispôsobovat' ich aktuálnym spoločenským okolnostiam v záujme divadla, ktoré je schopné pôsobit’ na zmenu spoločenských pomerov: „Kto vezme Brechta za slovo (je ortodoxný v užšom zmysle slova), sa neustále zaväzuje pri použití vlastnej metódy k neortodoxii, to znamená, k overovaniu diela pre publikum, nájdeniu takej interpretácie, ktorá je v danej situácii spoločensky nevyhnutná. “2 Vízia a koncepcia angažovaného, politického a spoločensky účinného divadla, rovnako ako model a metóda epického divadla, boli natol'ko novátorské a podnetné zároveň, že pretrvali dodnes a nad’alej ich rozvíjajú a modifikujú nové generácie divadelníkov.

\section{K Brechtovmu mysleniu o divadle a postupom}

Brecht nebol dogmatikom vlastných myšlienok, hoci revolučné divadlo sociálnej zmeny (v jeho vtedajšom ponímaní ho reprezentovalo divadlo socialistické a zároveň realistické) bral nadovšetko vážne. Videl v ňom možnosti zvládnutia l'udské-

\footnotetext{
${ }^{1}$ Werner Hecht bol od roku 1959 dramaturgom a najbližším spolupracovníkom Heleny Weiglovej v Berliner Ensemble. Po jej smrti sa stal riaditel'om Brechtovho centra a organizátorom mnohých vedeckých a publikačných aktivít, venovaných tvorbe B. Brechta.

${ }^{2}$ HECHT, W. Blick auf Brecht nach vorn. In Theater der Zeit, 1983, roč. 37, č. 2 , s. 11.
} 
ho osudu spoločnost’ou. ${ }^{3}$ Túžil po divadle, ktoré má silu spoločnost’ menit: „Divadlo sa musí pre skutočnost’ angažovat', aby mohlo a smelo vytvárat' účinné vyobrazenia skutočnosti!“4 Vzhl'adom na to, že bol vynikajúcim učitel’om, badáme v jeho vyjadreniach istý sklon k didaktickému formulovaniu názorov. Angažoval sa predovšetkým pri hl’adaní nových podôb a funkcií divadla vo vtedajšej vojnovej a povojnovej spoločnosti, ktorá sa ocitla v mravnej kríze. Meštianske divadlo a kultúru nazýval barbarskými, hladal niečo menej skompromitované a lepšie vyhovujúce novej dobe. Buržoáznu spoločnost’ a nerovnocenné kapitalistické vztłahy v spoločnosti vedúce k utrpeniu považoval za neludské, a preto pri ich divadelnom zobrazení neponúkal kladného hrdinu či morálneho vítaza.

Brechtova porovnávacia schéma dramatickej a epickej formy divadla vychádzala $\mathrm{z}$ potreby ozrejmit’ $\mathrm{v}$ čase prevládajúcich rezíduí meštianskeho a naturalistického divadla ${ }^{5}$ novú estetiku, ktorú objavoval a presadzoval v mene spoločenského účinku divadla. Neskôr však čiastočne revidoval svoje názory o epickom divadle a priklonil sa k termínu dialektické divadlo. Išlo mu o tvorivú a dynamickú metódu objektivizovania skutočnosti na základe vzájomne protirečivých vzt’ahov, ktoré má divadelné dielo ponúknut' (postihnút dialektickost') a o ktorých interpretácii či platnosti mal spolu s tvorcami kriticky a s odstupom premýšlat’ sám divák. Ked’že spoločnost’ sa neustále vyvíja a mení, pod vplyvom rôznych okolností sa mení aj doba. Preto sa musí uplatňovat’ vždy nová dialektika, čomu sa musia prispôsobovat’ aj divadelné postupy. Treba nájst' adekvátne divadelné prostriedky, metódy a techniky, ktoré vyzývajú divákov k premýšlaniu o dobe, ktorú žijú, a následne k spoločenskej zmene. ${ }^{6}$ V centre pozornosti reformátora Brechta stál teda najmä divák ako súčast’ spoločnosti. A ten mal zaujat' racionálny, premýšlavý a poučený vztah ku skutočnosti. Brecht optimisticky dúfal vo vytvorenie novej a spravodlivej spoločnosti, pri zrode ktorej malo stát’ aj divadlo.

Jeho názory, dramatická aj inscenačná tvorba boli v neustálom pohybe, čerpali potenciál z nových protirečení. Bernhard Reich, jeden z Brechtových spolupracovníkov v ranom období, v monografii venovanej tomuto tvorcovi uvádza: „V Brechtovej estetike má rozhodujúci význam skúmanie, o aký intelektuálny a emocionálny účinok na diváka sa má usilovat’ a akého sa vyvarovat.. " Svoje hry často prepisoval a prerábal na nové verzie podl'a toho, aké podnety do spoločensko-politického diania aktuálne vstupovali. Metodikou demonštratívnej hry ${ }^{8}$, ktorú vyvinul a uplatňoval tiež pri dramatickom texte, sa snažil pôsobit’ na divákov intelekt, prinútit’ ho k diskusii a vol'be osobného postoja: „V odhalení estetickej zložky intelektuálneho prejavu konajúcich postáv videl Brecht ešte d’alšiu emocionálnu účinnost' umenia, vynikajúceho pravdou a obraznou silou. ${ }^{\prime 9}$ To predpokladalo divadlo, ktoré prináša dialektiku dobra a zla

\footnotetext{
${ }^{3}$ BRECHT, B. Socialistický realizmus v divadle. [Nepublikované]. Bližšie pozri REICH, B. Bertolt Brecht. Praha : Orbis, 1974, s. 175.

${ }^{4}$ BRECHT, B. Myšlenky. Praha : Československý spisovatel, 1958, s. 97.

${ }^{5}$ Divadla okázalého, popisného, emocionálneho až sentimentálneho a samoúčelného.

${ }^{6} \mathrm{~V}$ praxi to znamená, že by mohlo logicky dochádzat aj $\mathrm{k}$ premene prostriedkov a prvkov epického divadla, resp. ich podoby.

${ }^{7}$ REICH, B. Bertolt Brecht, s. 199.

${ }^{8}$ Bližšie k metóde demonštratívneho predvádzania pozri tamže, s. 214 - 217.

9 Tamže, s. 215.
} 
(v deji aj pri kreovaní postáv $)^{10}$, nestavia na hereckom splynutí s postavou a stvárnení krajných emócií, stráni sa citového zaangažovania diváka, pretože jeho cielom nie je prinášat’ ojedinelé (a preto nepravdepodobné či málo pravdivé) katastrofy, ale demonštrovat' všeobecnú platnost’ a konkrétnoste životných situácií. Jeho hry tak zákonite nemohli mat’ ani pozitívne, resp. jednostranné konečné riešenia. Akoby tým dramatik Brecht vravel, že pokým sa nezmení spoločnost', nezmení sa ani jednotlivec, a naopak. V nezmenenom stave spoločnosti niet ani pre drámu a divadlo vítazov či porazených. Všetci spoločne sme zodpovední za nemennost', ale aj za zmeny, ktoré nás ovplyvňujú. Uvedomením si toho, že kumulovanie negatív nemôže mat’ nikdy pozitívne riešenie, dokáže divák nadobudnút kritický odstup od diela. Ten ho však nevedie $\mathrm{k}$ pasivite, $\mathrm{k}$ prijatiu bezvýchodiskovosti, ale naopak, k neotrasitel'nej a silnej túžbe po náprave.

Spomenuli sme, že Brecht ako dramatik svoje diela často aktualizoval a prerábal. Bežne pracoval na viacerých dielach súčasne, dopisoval repliky pre hercov počas divadelných skúšok, jedna hra mala niekol'ko rôznych verzií. S obl'ubou prepisoval staršie literárne diela, privlastňoval si ich časti, väčšie celky, dokonca celé fabuly (napr. Opera za tri groše $e^{11}$, Pán Puntila a jeho sluha Matti, Kaukazský kriedový kruh, Pušky pani Carrarovej, Antigona ${ }^{12}$ a. i). Plagiátorstvo bolo podl'a neho nevinnou a prirodzenou $^{13}$ "súčastou remesla spisovatela" ${ }^{14}$, najmä čo sa týka drámy. Manželka Brechtovho blízkeho spolupracovníka, skladatel’a Kurta Weilla, herečka Lotte Lenya Weillová v roku 1955 napísala: „Môj berlínsky priatel’ z tých dávnych čias mi raz povedal: Každé diet’a predsa vie, že Brecht neberie vel’mi vážne duševné vlastníctvo. Pravdaže kradne, ale kradne s genialitou, a o to ide. “15

Hoci Brecht pristupoval k literárnym predlohám iných autorov vel'mi slobodne, on sám pri ich úpravách $\mathrm{v}$ mene princípov epického divadla postupoval konzekventne. Drámu vnímal v kontexte jej budúcej javiskovej podoby, pričom sa usiloval o taký účinok, ktorý by divákov (celú spoločnost') motivoval k angažovanému spoločensko-politickému postoju.

\section{Poetika Brechtových hier}

Brechtova dramatická tvorba je rôznorodá, a to tak tematicky, ako aj miešaním žánrov, no konzistentná v postoji tohto tvorcu k spoločnosti, čo zároveň úzko súvisí

\footnotetext{
${ }^{10}$ Porovnaj: „(...) nijako sa neusiloval mentorsky potrestat’ zlo na javisku - to je presne to l'ahké a povrchné riešenie, ktoré odmietal.“ PORUBJAK, M. Brecht na slovenskom profesionálnom javisku. In Slovenské divadlo, 1975, roč. 23, č. 2, s. 195.

${ }^{11}$ Tento titul je na Slovensku známy pod viacerými názvami. Originálny názov Die Dreigroschenoper bol preložený ako Opera za tri groše, Trojgrošová opera či Žobrácka opera.

${ }^{12}$ Pôvodný názov Brechtovej adaptácie Sofoklovej tragédie je Das Antigonenmodell. Na Slovensku bola hra uvedená ako Sofoklova Antigona. Takýto významový preklad názvu Brechtovej adaptácie je zaužívaný aj v iných krajinách.

${ }^{13}$ BRECHT, B. Was den Fall des Herrn Kerr betrifft,... [Rukopis]. [online]. [cit. 17. 3. 2020]. Dostupné na internete: http://www.brecht-notizbuecher.de/content/uploads/bba-10332.058-059.pdf.

${ }^{14}$ BRECHT, B. Zur Plagiatsbeschuldigung Gilbrichts. In Werke : Große kommentierte Berliner und Frankfurter Ausgabe. Band 22. W. Hecht at al (eds.). Berlin : Aufbau-Verlag ; Frankfurkt am Main : Suhrkamp Verlags, 1992, s. 399.

${ }^{15}$ LENYA-WEILL, L. Das waren Zeiten. In Bertolt Brechts Dreigroschenbuch. 1. zväzok. (Ed. S. Unsel). Frankfurt am Main : Shurkamp Verlag, 1960, s. 328.
} 
s jeho vnímaním spoločenskej funkcie divadla. Pre prvé obdobie je typická inklinácia k lyrike, expresionizmu, mladíckemu buričstvu. Neskôr pribúdajú inšpirácie ludovou fraškou i melodrámou, epická konštrukcia otvára priestor pantomíme, štylizácii aj diskusii. Koncom dvadsiatych rokov 20. storočia zaznamenávame Brechtov príklon k marxistickej ideológii, píše sériu didaktických hier a náučných podobenstiev (tzv. paraboly). Skúsenost' 2 . svetovej vojny a najmä vstup do tzv. atómového veku ho donútili prehodnotit’ svoje predošlé postoje. Predvojnové didaktické modely a marxisticky ladené hry tak nahrádzajú spoločensko-kritické dialektické hry a paraboly ${ }^{16}$, viaceré staršie hry prerobil na nové verzie (napr. Život Galileiho, Matka Guráž a jej deti, Dobrý človek zo Sečuanu, Švejk v druhej svetovej vojne, Kaukazský kriedový kruh).

\section{Ako pristupovat' k Brechtovým hrám}

Z Brechtovho opakovaného prerábania hier vyplývali isté problémy, a to nielen pre slovenský inscenačný kontext. Tvorcovia sa niekedy mylne prispôsobovali vo svojich koncepciách dobovému zaradeniu jeho prvých verzií hier, resp. adaptácií do troch základných období, a neaplikovali Brechtovu kl’účovú myšlienku - pristupovat’ k inscenovaniu hier z hl'adiska aktuálnych potrieb človeka, spoločnosti a umenia. ${ }^{17}$ No Brecht mal v otázke pietneho prístupu k dramatickému textu vždy jasno: „Na otázku inscenátora, či možno zobraził’ príbeh, ktorý pochádza z inej epochy úplne v zmysle autora, Brecht odpovedal: ,Nie. Inscenátor si má zvolit taký spôsob interpretácie, ktorý zaujíma jeho vlastnú epochu. "“18

Do slovenského divadla vstúpilo inscenovanie hier Bertolta Brechta, na rozdiel napr. od českého divadla, pomerne neskoro, až po 2. svetovej vojne. Bolo to logické z vnútro-umeleckých, organizačných i spoločensko-politických dôvodov. Slovenské národné divadlo vzniklo až v roku 1920, umelecké zložky sa len postupne profesionalizovali, prevažovali iné potreby a funkcie divadla než brechtovské, o ktorých sme písali vyššie. Ďalším dôvodom bola výrazná inklinácia slovenského divadla k opisno-realistickej estetike a psychologickému herectvu, pre ktoré bolo príznačné emocionálne prežívanie, vel'ké gesto, deklamácia a celková ilustratívnost'.

V tomto smere zohrala zrejme dôležitú úlohu tiež postupná profesionalizácia nášho divadla, ktoré od konca štyridsiatych rokov 20. storočia nachádzalo svoje oficiálne sídla v krajských mestách, z čoho vzišla potreba diferenciácie divadelnej siete. V medzivojnovom období bolo nepredstavitel'né uvádzat’ Brechta z ideologických dôvodov, nebolo možné, aby dramaturgie nasadili na repertoár hry tohto l'avicového intelektuála a spoločenského kritika. Naopak, v šest’desiatych a sedemdesiatych rokoch 20. storočia sme zaznamenali doslova brechtovskú módnu vlnu.

Po prvýkrát inscenovali Brechta na Novej scéne Národného divadla v roku 1947. Neskôr nasledovali divadlá vo Zvolene (1962), Prešove a Trnave (1963), Košiciach (1972) a napokon v Nitre (1974). Celkovo sa na našich javiskách uviedlo v činoherných profesionálnych divadlách (vrátane školských divadiel a divadiel národnost-

${ }^{16}$ Brecht takto označil niektoré svoje hry (podobenstvá), pretože v nich vytváral parabolické podobenstvá.

${ }^{17} \mathrm{O}$ uvažovaní o Brechtových hrách z hl’adiska ich dobovej klasifikácie nachádzame dôkazy vo viacerých inscenačných bulletinoch, kde na ne z tejto dramaturgickej perspektívy inscenátori nahliadajú.

${ }^{18}$ HECHT, W. Blick auf Brecht nach vorn. In Theater der Zeit, s. 12. 
ných menšín) 49 inscenácií šestnástich rôznych titulov. Bolo medzi nimi jedno bábkové spracovanie, jedna pantomíma a poetické pásmo v podobe koláže Brechtových básní.

O Brechtovi na slovenskom profesionálnom javisku napísal rozsiahlu štúdiu teatrológ Martin Porubjak, ktorý sledoval rozpätie rokov $1947-1974 .{ }^{19} \mathrm{~V}$ texte publikovanom v časopise Slovenské divadlo v roku 1975 konštatoval skromné uvádzanie hier tohto dramatika, ktoré sa dramaturgie divadiel postupne snažili rozširovat', čo bolo už samé o sebe považované za prelomový počin. Porubjak koncipoval štúdiu ako skúsenostný rámec našich divadiel s iným typom dramatiky, estetiky, herectva a pod. Formuloval a interpretoval zákonitosti Brechtovej metódy, objavné scénické, dramaturgické, režijno-herecké výsledky, aj omyly našich divadiel. Najviac ocenil Žobrácku operu ${ }^{20} \mathrm{v}$ réžii Magdy Lokvencovej na Novej scéne Národného divadla (1947) a Život Galileiho v SND (1958) v réžii Tibora Rakovského. ${ }^{21}$ V závere štúdie Porubjak konštatoval podobný stav nášho divadla v polovici sedemdesiatych rokov ako na konci štyridsiatych rokov 20. storočia: „Osvojit’ si Brechta komplexne - teda nielen jeho filozofiu, lež aj jeho umeleckú metódu - to je úloha, ktorá slovenské divadlo ešte len čaká. Metodicky totiž Brecht nepriniesol vel’a do nášho divadla - a iste nie svojou vinou. "22

\section{Pokračujúca inscenačná tradícia}

V nadväznosti na citovanú štúdiu Martina Porubjaka zameriame našu pozornost' na d’alšiu inscenačnú dekádu hier Bertolta Brechta na slovenských profesionálnych činoherných javiskách, konkrétne na roky 1975 - 1985.

V období po roku 1975, hoci tradícia inscenačnej praxe Brechtových hier trvala u nás už takmer tridsat’ rokov a inscenácií pribúdalo, pokračovala rétorika našej neskúsenosti s týmto dramatikom. Nachádzame ju vo väčšine divadelných recenzií ako isté ospravedlňujúce klišé a povzbudenie pre dramaturgov a dramaturgie divadiel v uvádzaní jeho hier. Kritickejšie vyjadrenia sa týkali vtedajších predstáv o režijnej estetike a hereckej technike epického divadla a ich prenesenia do javiskovej praxe. K aktuálnosti interpretácií a angažovanému divadelnému gestu sa pristupovalo skôr opatrne, v intenciách protiburžoázneho, protimeštiackeho a protivojnového spoločensko-kritického pohl'adu. Aj na začiatku osemdesiatych rokov ešte nájdeme v diva-

\footnotetext{
${ }^{19} \mathrm{~V}$ sedemdesiatych rokoch boli na slovenských javiskách uvedené Brechtove hry v nových prekladoch. Popri Móricovi Mittelmanovi Dedinskom sa tak na naše javiská dostali napríklad preklady od Juraja Váha, Júliusa Lenka a Martina Porubjaka, ktorý ako dramaturg v divadlách presadzoval o. i. modernú a súčasnú nemeckú drámu.

${ }^{20} \mathrm{~V}$ origináli Die Dreigroschenoper.

${ }^{21}$ Lokvencovej inscenáciu ocenil najmä pre jej syntetickú koncepciu, priblíženie javiska s hladiskom, ba priam s ulicou (žobráci pochodovali za sprievodu hudby z verklíka schodmi pred divadlom, foyerom a hlladiskom na javisko), využitie štylizácie jarmočnej balady, zlúčenie poučnosti a zábavnosti, činohry so spevom, zbavenie sa povrchnej empiricko-psychologickej vrstvy našej inscenačnej tradície. Lokvencovej logika mu nesplývala so životnou logikou, a teda jej inscenácia nebola odrazom sveta, ale obrazom o svete. Rakovského vyzdvihol pre jeho interpretáciu hry ako hry argumentov a protirečení, čím si režisér i herci osvojili Brechtovu objektívnu metódu. Podla Porubjaka sa tu podarilo priam prelomovo prekonat' mnohé predsudky a zaužívané divadelné postupy v práci s hercom (zbavenie sa ornamentálnosti a povrchnej či vonkajšej citovosti), hudbou a scénografiou (zbavenie sa historizujúceho akcentu a iluzívnosti). Bližšie pozri PORUBJAK, M. Brecht na slovenskom profesionálnom javisku. In Slovenské divadlo, 1975, roč. 23, s. 193 - 204.

${ }^{22}$ Bližšie pozri tamže, s. 220.
} 
delných kritikách názory, že Brecht nemal na našich javiskách privel’a štastia a neinscenoval sa príliš často. Táto všeobecná téza sa u nás doslova udomácnila, hoci by sa dalo súhlasit’ len s jej prvou častou. Kým skúseností pribúdalo, inscenátori len zriedkavo presvedčili o svojej pripravenosti preniest' na javisko brechtovskú poetiku a estetiku epického divadla. Klesavú tendenciu uvádzania Brechtových hier zaznamenávame až po roku 1989. Ak sa udiala zmena, tak v tom, že sa záujem o ne sa presunul z bratislavských scén, odkial' sa takmer vytratili, do mimobratislavských divadiel.

Po roku 1975 sa dramaturgie slovenských profesionálnych divadiel zamerali skôr na tie hry, s ktorými už tvorcovia mali predošlé skúsenosti ${ }^{23}$, alebo ktoré v minulosti zaznamenali úspech u publika. Nových (resp. ešte neuvedených) hier do portfólia divadelných skúseností pribudlo len skromne (Malomeštiakova svadba, Dobrý človek zo Sečuanu, Baal, Antigona). Slovenské divadlá nepristupovali k inscenovaniu Brechtových hier či k tvorivému využívaniu jeho estetiky epického divadla programovo a koncepčne, ale náhodne. Išlo viac o dramaturgické iniciatívy, o pokusy síce novátorské, ale len v zmysle overovania svojich síl pri kontakte s iným typom divadelnosti. Snahy o formálne napíňanie inscenačných princípov epického divadla boli prevažne neúspešné, absentovalo výraznejšie skĺbenie aktuálneho spoločenského kontextu s inscenačnou formou, ale aj kritická polemika vtedajších tvorcov s brechtovskou tzv. revolučnou morálkou.

V roku 1975 uviedla Poetická scéna Bratislava hru Muž ako muž v réžii Stanislava Párnického. Boli to len štyri mesiace po prvej slovenskej premiére tohto titulu v Krajovom divadle Nitra. Poetická scéna už mala predchádzajúcu skúsenost’ s inscenovaním pásma Brechtových básní pod názvom Ranná reč k stromu (1972) v réžii Marty Gogálovej. Ďalší pokus možno teda vnímat’ ako programové úsilie o istú nadväznost’ a rozšírenie skúsenostného rámca.

Bratislavská inscenácia $M u z ̌$ ako muž bola odlišná od nitrianskej, v ktorej hlavná postava v podaní Jozefa Bednárika vyznievala ako obet’ mašinérie, čo bolo v rozpore s Brechtovým zámerom. Príbeh nakladača Galyho Gaya (L’ubo Gregor), odohrávajúci sa vo vojenskom tábore v Kalkate v roku 1925, režisér Párnický koncepčne spracoval v duchu brechtovského politicko-spoločenského protestu. Obnažil tvrdost’ poetických, ironických a analytických spojov textu, čím dostali myšlienkové a situačné vztahy nové dimenzie: „Režisér Stano Párnický zbytočne nefilozofuje, vytvára premyslený a dôrazný obraz o procese odludštenia prostriedkami frašky, komediálnej nadsázky, irónie, hyperbolizácie (...). ${ }^{\text {24 }}$

Režisér s upravovatel'om Štefanom Havlíkom to dosiahli aj vd’aka úpravám v texte a posilnenej funkcii rozprávača. Záver hry presunuli na jej začiatok, čím sa vytvoril priestor pre dialektiku procesu premontovania hlavnej postavy - apolitického človeka, ktorý nevie povedat' nie - na vraždiaci mechanizmus. ${ }^{25} \mathrm{Z}$ tejto perspektívy inscenácia vyznievala ako metafora násilného pretvárania myslenia l'udí, ba celých

${ }^{23}$ Išlo o komediálne ladené hry Žobrácka opera a Muž ako muž, paraboly a kritické irónie Pán Puntila a jeho sluha Matti, Kaukazský kriedový kruh, Dobrý človek zo Sečuanu, ale aj protivojnové hry a hry riešiace spoločenskú zodpovednost' či zodpovednost’ vedy, obsahujúce Brechtove politické úvahy, napr. Život Galileiho, Pušky pani Carrarovej, Matka Guráž a jej deti.

${ }^{24}$ NAVARA, A. Dva pohl’ady na jedného muža. In Film a divadlo, 1975, roč. 19, č. 16, s. 25.

${ }^{25}$ Začiatok hry tak uvádzal divákov do príbehu o človeku, ktorého ešte len mienia premontovat', a zároveň prezrádzal výsledok tohto procesu, teda ako príbeh hlavnej postavy Galyho Gaya skončí. Inscenátori sa tak mohli sústredit na protirečivý proces, akým sa premena hlavnej postavy odohrala. 


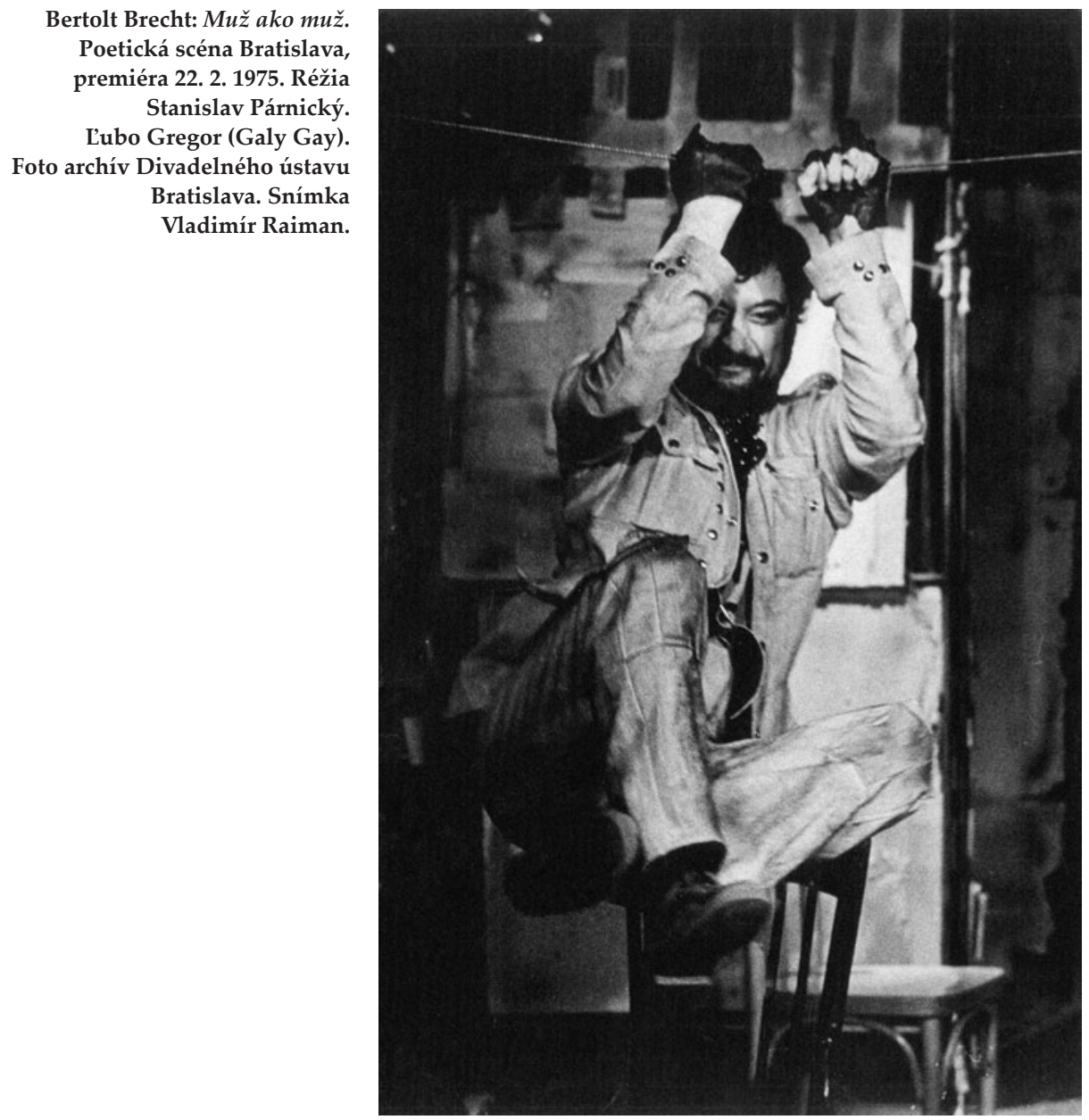

národov podl’a toho, ako sa to hodí ekonomickým a mocenským silám. Problém časového a geografického situovania sa takto podarilo eliminovat’ a sprostredkovat' vlastnú výpoved'. V domácom politicko-spoločenskom kontexte išlo o odvážne spoločenské gesto tvorcov, ktorí prostredníctvom divadla podali šifrovanú výpoved'. Diváci mohli porozumiet’ ich odmietavému postoju voči okupácii Československa (1968), ale najmä ju vnímat’ ako kritiku normalizácie, ktorá nasledovala a v ktorej práve žili.

Na malom javisku s variabilnou scénou Jozefa Cillera sa uplatnilo hravé, artistné a významové herectvo fyzickej akcie. Ťažiskom inscenácie bola bohatost' hereckých výrazových prostriedkov, zdôraznenie premenlivosti či pohybu priestorových a medzil'udských vztahov. Jednotlivé kreácie pripomínali priam gymnastické cvičenia, jarmočné divadlo - každé gesto, pohyb, použitie mimiky bolo presné a koncentrované, podriadené režijnej koncepcii: „Najúchvatnejšie sú vypracované rôzne sa obmieňajúce scény psychického a fyzického nátlaku na nakladača Galy[ho] Gaya, ktoré akcentujú obludnost’ takéhoto konania. Možno povedat', že režijná koncepcia kládla 


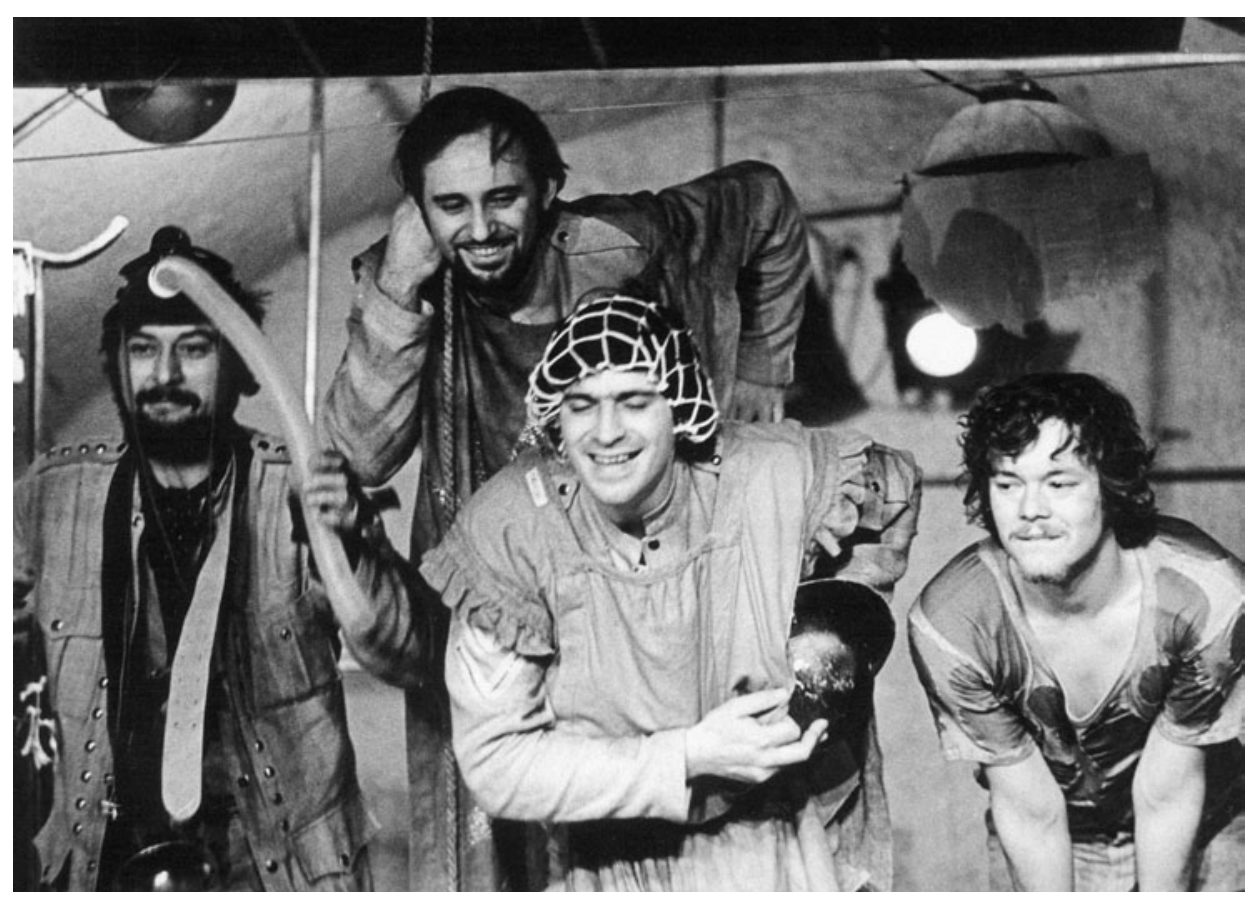

Bertolt Brecht: Muž ako muž. Poetická scéna Bratislava, premiéra 22. 2. 1975. Réžia Stanislav Párnický. Zlava L’ubo Gregor (Galy Gay), Ján Veneni (Uria Shelley), Ján Mistrík (Jesse Mahoney), Vlado Černý (Polly Baker). Foto archív Divadelného ústavu Bratislava. Snímka Vladimír Raiman.

najväčší dôraz na vyjadrenie odporu k násiliu, páchanému na človeku, a nie na druhú stránku veci - že na vine je aj ten, kto nevie povedat’ nie. ${ }^{26}$

Napriek tomu, že sa v recenziách spomínajú aj isté rezervy hereckého súboru (rečový prejav, expresivita podania, fyzická kondícia), jej prínos spočíval v tom, že na Galyho Gaya nenazerala ako na obet’ zavlečenú do vojnových sporov, ale upozorňovala na fakt, že človek si svoje miesto v živote určuje sám: „(...) je to od prvej chvíle práve tak babrák ako špekulant, naivka ako krysa a je ochotný - obrazne povedané - nazriet’ vždy do d’alšej komnaty, až kým s gul'ometom v ruke nevkročí do tej poslednej, trinástej. Tam Brechtova hra končí. ${ }^{27}$

Pri bratislavskej inscenácii $M u z ̌$ ako muž zohrala z divadelného hladiska významnú úlohu aj d’alšia okolnost' - zrušenie Divadla na korze a presunutie jeho hereckého súboru do činohernej časti divadla Nová scéna. Poetický súbor Novej scény, ktorý tvorili aj bývalí členovia Divadla na korze, od roku 1972 pôsobil v priestoroch bývalého Divadla na korze ako samostatná Poetická scéna. Inscenáciu hry ako podobenstva normalizácie a jej účinkov na spoločnost’ mohli diváci sledovat’ priamo v pivničnom priestore bývalého Divadla na korze, zatvoreného v roku 1971 na základe politického rozhodnutia.

\footnotetext{
${ }^{26}$ MISTRÍK, M. Brechtov návrat. In Pravda, 1975, roč. 56, č. 60, s. 4, 12. 3.1975.

${ }^{27}$ NAVARA, A. Dva pohl'ady na jedného muža. In Film a divadlo, s. 25.
} 


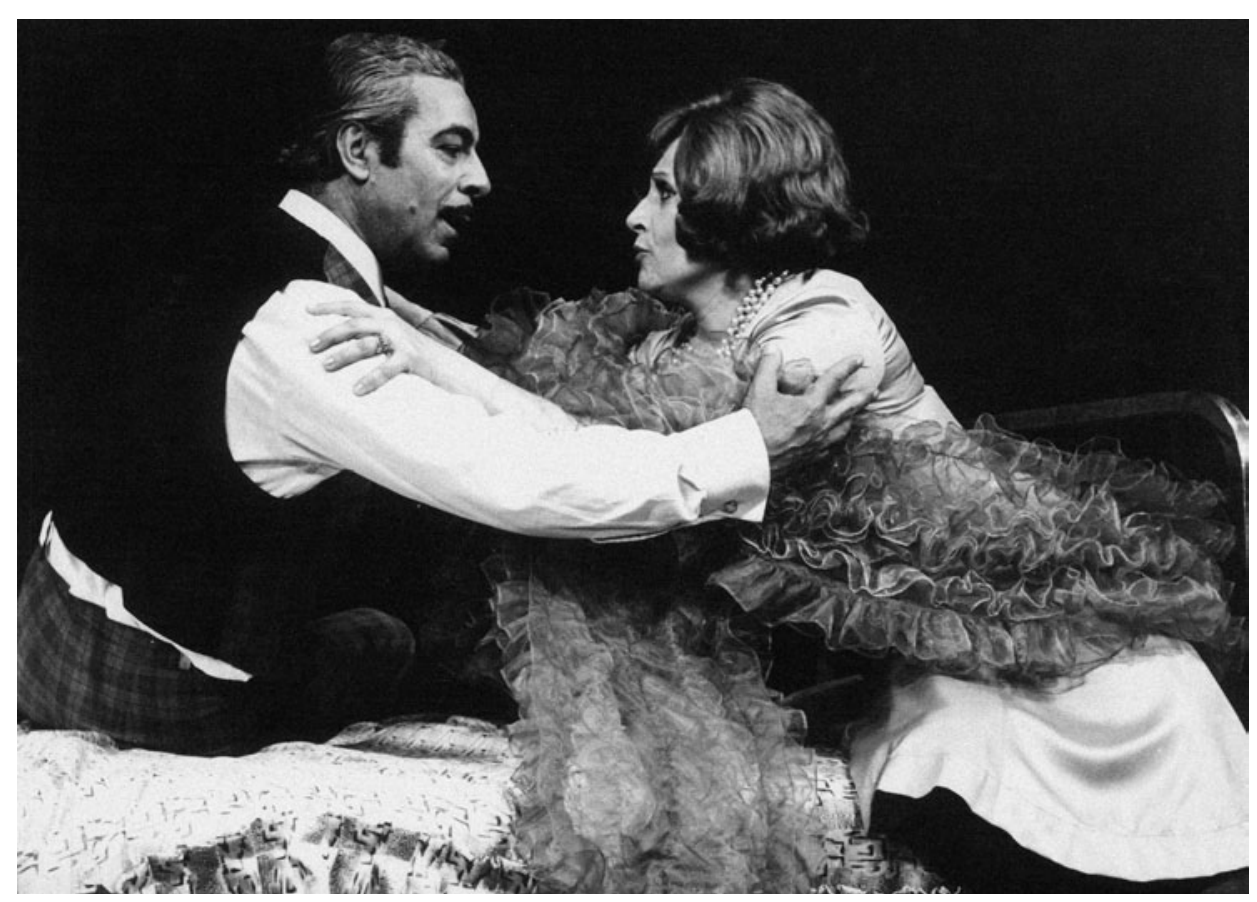

Bertolt Brecht: Žobrácka opera. Štátne divadlo Košice, premiéra 24. 5. 1975. Réžia Vladimír Petruška. Anton Gymerský (Macheath), Darina Poldaufová (Polly Peachumová). Foto archív Divadelného ústavu Bratislava. Snímka Edita Matečíková.

Ďalšou inscenáciou v tom istom roku bola Žobrácka opera v réžii Vladimíra Petrušku (Štátne divadlo Košice, 1975). Režisér a súbor košického divadla mali už spoločnú skúsenost’ s Brechtom (dramatizácia Gorkého Matky) spred troch rokov. Titul s kabaretne a jazzovo ladenou hudbou Kurta Weilla teda predstavoval logickú vol'bu, vzhl'adom na operetnú a spevohernú profiláciu súboru. Vyvstávala však otázka, ako si jeho členovia poradia s postupmi antiiluzívneho divadla. Kým pri inscenácii Matky došlo $\mathrm{k}$ zladeniu princípov epického divadla s hereckými postupmi realistickej školy a tiež so scénografiou, v prípade Žobráckej opery bol Petruškov prístup výrazne odlišný. Rozhodol sa ju inscenovat’ ako divácky atraktívny tvar, čo by zodpovedalo Brechtovým požiadavkám na zábavnost’ diela, no vonkajšia forma v tomto prípade prekryla spoločensko-kritickú rovinu hry.

Ján Hanák vybudoval scénu z obrovských rúr potrubia, aké sú v podzemných kanáloch. V takomto scénografickom riešení sa odohrával príbeh o Macheathovi (Mackiem Messerovi), človeku, ktorý bol prototypom etablovaného a šarmantného meštiaka, elegantného gangstra so zubami ostrými ako nože, a zároveň celej spoločnosti, ktorej sa krivol'aké cestičky zločinu stávajú vlastnými. Výtvarné riešenie sprostredkovalo d’alšiu dimenziu možného výkladu hry. Jej ústrednou témou je rovnica: Gangstri sú meštiaci - sú meštiaci gangstri?, na ktorú by mala inscenácia odpovedat. Podzemie nehostinnej stoky, ktorú obývajú potkany a ilegálne živly, bolo synonymom nadzemného sveta prostitútok, podvodníkov, vydieračov, legalizovaného zločinu 
a korupcie, obrazom o spoločnosti v „slušnom šate“. Režisér v duchu žánru Žobráckej opery uplatnil music-hall, revuálne kostýmy, zakomponovanie orchestra na scéne, tanečné vsuvky ako ilustrácie sociálnych kontrastov spoločnosti. Operetné ladenie a viacnásobne dekoratívne použité tanečné choreografie baletného súboru však pripomínali viac hudobnú veselohru než kritickú iróniu, išlo väčšmi o „pôžitok pre oči, než potravu pre rozum“28.

Celkovo bola inscenácia kritikmi i divákmi prijatá pozitívne. Kritička Nelly Štúrová v recenzii uvádza: „Sotva by však bolo možné odobrit takúto vonkajšiu formu, keby prehlušila vlastný ideový náboj hry alebo prekryla jej spoločensko-kritické ambície lacnou zábavou. Takýmto nástrahám sa režisérovi podarilo uniknút hlavne vd’aka správnemu vedeniu hercov, ktorí pri tvorbe svojich postáv v plnej miere využili odcudzovací efekt a docielili tak kritický odstup a potrebné intelektuálne hodnotenie stvárňovaných charakterov i situácií. Týka sa to predovšetkým troch klúčových postáv.“29 Zároveň však dodáva, že „režisér neuplatnil svoje povinnosti zjednocovatel’a či korektora jednotlivých rukopisov a narušil mieru revuálnosti a jej spochybňovania" ${ }^{\prime 30}$.

Je zrejmé, že prenikanie tvorcov do inej inscenačnej poetiky a osvojovanie si aspoň jej elementárnych princípov nebolo jednoduché. Svoju úlohu tu zohrávala aj režijná predstava o Žobráckej opere ako scénicky prítažlivom, takmer vel’kovýpravnom diele, ktoré má byt' pre divákov predovšetkým atraktívne a zábavné.

$\mathrm{V}$ pomerne krátkom časovom odstupe sa opät inscenovala hra $M u \check{z}$ ako muž (1976). Tentokrát to bola prvá skúsenost’ s Brechtom pre Ukrajinské národné divadlo v Prešove a režiséra Jaroslava Sisáka. Pokusy priblížił princípy brechtovského divadla narážali v slovenskom divadelníctve od počiatku na problémy spojené s komunikatívnostou diela a javiskového pretlmočenia myšlienky hry. UND vstúpilo do konfrontácie s ostatnými divadlami, ktoré zaznamenali úspešné i menej úspešné uvedenia tohto titulu, a pridalo sa k dovtedy úspornému uvádzaniu Brechta na východnom Slovensku. Prekladatel' Viktor Hajný hru preložil ako Soldat jak soldat. Dôrazom na vojenské prostredie mohol nastat' skreslujúci posun.

Inscenácia sa odohrávala $\mathrm{v}$ komornom priestore zmenšeného javiska, herci sa pred očami divákov obliekli do uniforiem a nasadili si masky, čím sa medzi nimi odstránili individuálne rozdiely. Takto zvolené riešenie zdôraznilo mašinériu vojny či armád, ale vzdialilo sa od celospoločenského kritického kontextu hry. Režisér premontovanie Galyho Gaya, ktorého pohltí vojenský mechanizmus, až napokon v sebe zaprie človeka, overoval na vzt’ahovej osi jedinec - celok - jedinec. Vzt’ahy medzi vojakmi sa hierarchizovali postupne, uprostred dramaticky vypätej situácie herci prerušili príbeh, obrátili sa na divákov a deklamatívne tlmočili neviditel'né motívy konania zvyšných aktérov. Sisák využil tiež prvky ataku na diváka, ktoré striedal s vtipnou uvolnenou hereckou akciou a rytmizovaním reči, udávajúcej takt pochodujúcich vojakov. Songov typických pre epické divadlo sa zriekol. Postup dynamickej hereckej akcie a ku nej kontrastnej statickej deklamácie sa stal nosným pre celú inscenáciu. Režisér prepájal realistické herectvo s antiiluzívnymi postupmi, no nepodarilo

\footnotetext{
${ }^{28}$ MISTRÍK, M. Žobrácka opera ako opereta? In Pravda, 1975, roč. 56, č. 135, s. 5, 11. 6. 1975.

${ }_{29}^{2}$ ŠTÚROVÁ, N. Interné hodnotenie. In Divadelný ústav Bratislava : Zbierka inscenácií. Brecht, B. Žobrácka opera, 24. 5. 1975, ŠD Košice, s. 2.

${ }^{30}$ Tamže, s. 3.
} 


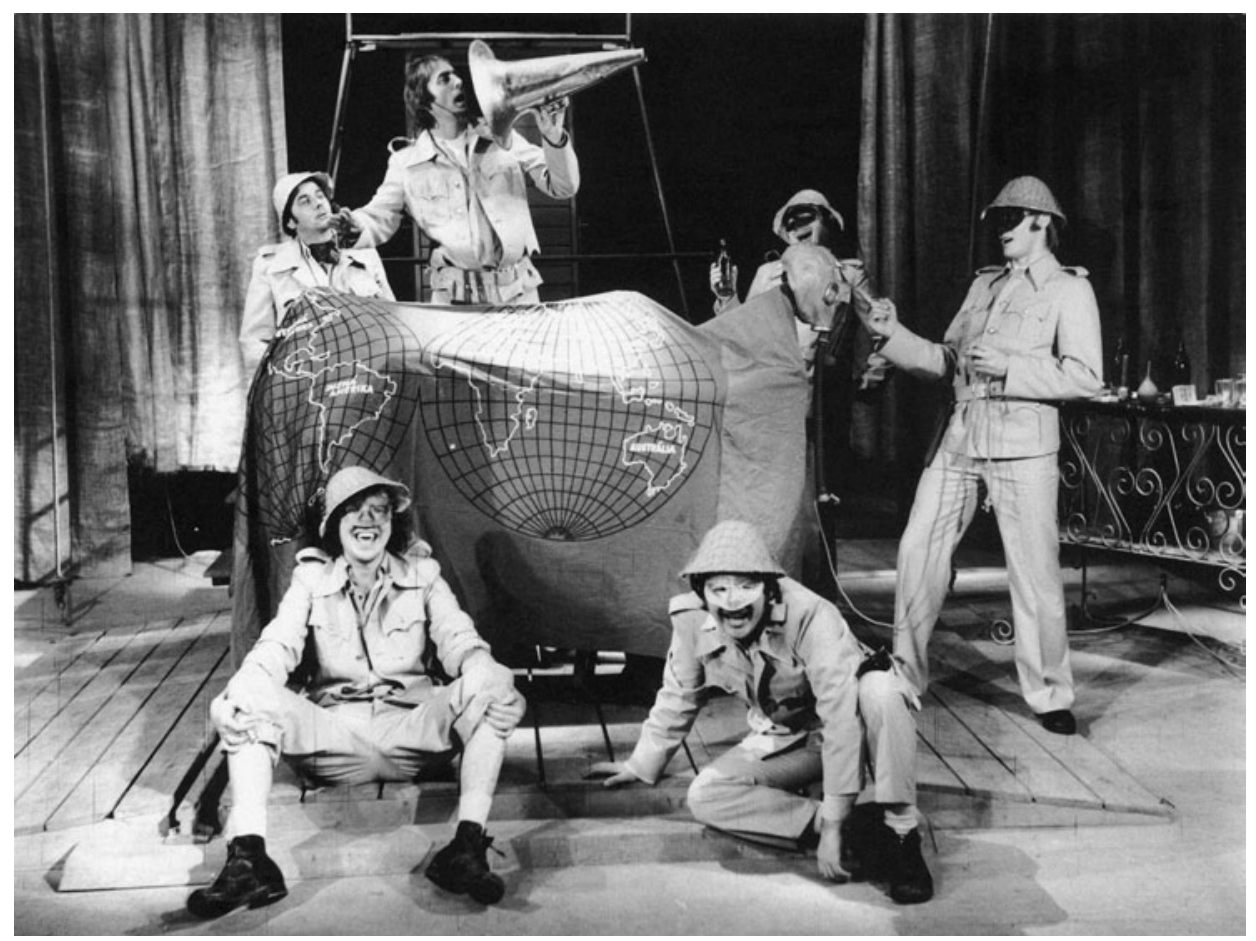

Bertolt Brecht: Muž ako muž (Soldat jak soldat). Ukrajinské národné divadlo Prešov, premiéra 4. 12. 1976. Réžia Jaroslav Sisák. Scéna Predaj slona. Foto archív Divadelného ústavu Bratislava.

sa mu ich zjednotit do tej miery, aby nepôsobili ako zmes cudzorodých štýlových prvkov: „Transpozíciu Galy[ho] Gaya Sisák odkrýva po častiach. Jednak v príhovoroch sa naznačuje očakávané prerobenie, jednak v dramatickom konaní. No prílišná snaha o používanie čisto divadelných prostriedkov viedla k neprehl'adnosti a nejednoznačnosti inscenácie." ${ }^{\text {31 }}$

Prešovská inscenácia Muž ako muž bola pokusom o syntetické divadlo, kde na seba občas kompozične narážali prvky totálneho psychologického a epického antiiluzívneho divadla. Pre UND to bol experiment, v ktorom sa usiloval nebrat' Brechtov text ako striktné inscenačné východisko, ale pokúsit’ sa o vlastnú inováciu.

Prvé stretnutie s Brechtom zaznamenalo aj Mad’arské oblastné divadlo v Komárne, ked’ v réžii Edmöda Takátsa inscenovalo dve jednoaktovky pod názvom Pušky pani Carrarovej (Carrar asszony puskái) a Sofoklova Antigona (Phoklész Antigonéja) (1977). Z dramaturgického hl'adiska vytvárali hry tematický celok. Brecht v oboch zvýraznil boj proti fašizmu a tyranii a zastal sa demokratických ludských práv. Pušky pani Carrarovej pôvodne napísal ako didaktickú agitku, vhodnú aj pre ochotníkov. Prostá žena, ktorá zastávala názor, že chudobní nemôžu viest’ vojnu, po strate manžela i staršieho syna dáva pušky do rúk mladšiemu synovi a sebe so slovami: No

${ }^{31}$ ŠÁRIK, L'. Muž ako muž. In Film a divadlo, 1977, roč. 21, č. 7, s. 24. 
pasarán! Antigone pripísal Brecht predohru, v ktorej dve sestry - Berlínčanky pred aprílom 1945 - stoja pred otázkou, či popraveného brata-zbeha odrezat’ zo šibenice. Komárňanský súbor však uviedol predohru i prológ ${ }^{32}$, ktorý autor dopísal k hre až v roku 1951 ako aktualizačný prvok pre uvedenie hry v mestečku Greiz (aby mohla byt’ vynechaná predohra). V kritikách lepšie obstála druhá jednoaktovka, a to vd’aka stvárneniu Kreonta ako Hitlera. No v oboch inscenáciách sa prejavila technická nepripravenost’ súboru: „Bezradnost’ režiséra zmiatla hercov, ktorí si nevedeli poradit s napohlad nedramatickým epickým textom a v konfrontácii s neosvojenou brechtovskou poetikou ich nevycibrené, intelektuálne nevyhranené výrazové prostriedky pôsobili ako prejav amatérskej snahy. “33

Opačným prípadom bola inscenácia jednoaktovky Malomeštiakova svadba v Krajovom divadle Nitra v réžii Ivana Krajíčka (1978). Kritici inscenáciu unisono označili za dramaturgický objav i režijný a herecký koncert. ${ }^{34}$ Príbeh svadobnej hostiny, počas ktorej sa odkrývajú netušené vztahy jej účastníkov a spolu s ich morálkou sa rozkladá aj ženíchov nábytok podarovaný neveste ako svadobný dar, bol vol'bou, ktorá našla invenčného režiséra i pripravených hercov. Dramaturgicky išlo o prvé slovenské uvedenie Brechtovej zabudnutej ludovej hry z roku 1919. ${ }^{35}$ Ivan Krajíček režijne využil prvky činohernej zábavy, grotesky, karikatúry a satiry. Jeho humor bol však drsný. Podobne zdrsnil Ján Štrasser texty piesní (hudba Pavol Hammel) a dodal im ešte jadrnejšie výrazy než použil sám Brecht. Groteskný obraz rozkladu starej meštiackej spoločnosti nebol v nitrianskej inscenácii jej neúprosným odsúdením ako u Brechta. Bohato sa využívala najmä herecká akcia zdôrazňujúca komickost' situácií. Zobrazenie rozkladu však nadobudlo dostatočne kritické kontúry na to, aby herci popri zábave upriamili divácku pozornost’ na slabé morálne miesta postáv, ktoré stvárňovali a karikovali. Do popredia tak vystúpil pôsobivo neokázalý výsmech malomeštiackych pováh a spôsobov, ktoré neboli vzdialené ani spoločnosti z konca 20. storočia. Rozohrávanie situácií a drobnokresba postáv, ktorá u Brechta chýba, aj kontrapunkt situácií a konania postáv sa pretavili v originálnych nápadoch. Z na prvý pohl’ad l’ahkej zábavy sa stala ostrá karikatúra, spoločenská satira meštiactva, ktoré už takmer stratilo svoju noetickú hodnotu. Ako napísal kritik Stanislav Vrbka, „odvtedy, čo Malomeštiakova svadba vznikla, malomeštiaci narobili viac zla a stali sa spojencami ovel'a temnejších síl, než je ich vlastná obmedzenost', hlúpost’ a samol'úbost' "“36.

Ivan Krajíček prácou s hercom premenil jednoaktovku na celovečernú hru. Scéna Tomáša Berku s pestrofarebným lustrom a najmä symbolicky zväčšeným krajkovým baldachýnom, pod ktorým sa kontrapunkticky k jeho bielobe rozkladal nábytok, dala priestor hereckej akcii, súhre, množstvu gagov, nápaditému fyzickému konaniu a mimicko-gestickým reakciám. Každý detail bol precízne rozpracovaný a konkreti-

32 Pozri F-a. Smelé, ale nedomyslené. Dve Brechtove jednoaktovky v Komárne. In Hlas ludu, 1977, roč. 23, č. 19, s. [3], 24. 1. 1977

${ }^{33}$ MAČUGOVÁ, G. Interné hodnotenie. In Divadelný ústav Bratislava : Zbierka inscenácií. Brecht, B. Pušky pani Carrarovej; Sofoklova Antigona, 14. 1. 1977, MOD Komárno, s. 2.

${ }^{34}$ Porovnaj napr. F-a. Dramaturgický objav - režijný čin - herecký koncert. In Hlas l'udu, 1978, roč. 24, č. 30, s. [4], 4. 2. 1978.

${ }^{35}$ Sám Brecht túto jednoaktovku nezrežíroval a v portfóliu jeho tvorby upadla do zabudnutia. Európski režiséri ju z tohto dôvodu začali inscenovat' pomerne neskoro od doby jej vzniku.

${ }^{36}$ VRBKA, S. Interné hodnotenie. In Divadelný ústav Bratislava : Zbierka inscenácií. Brecht, B. Malomeštiakova svadba, 28. 1. 1978, Krajové divadlo Nitra, s. 3. 


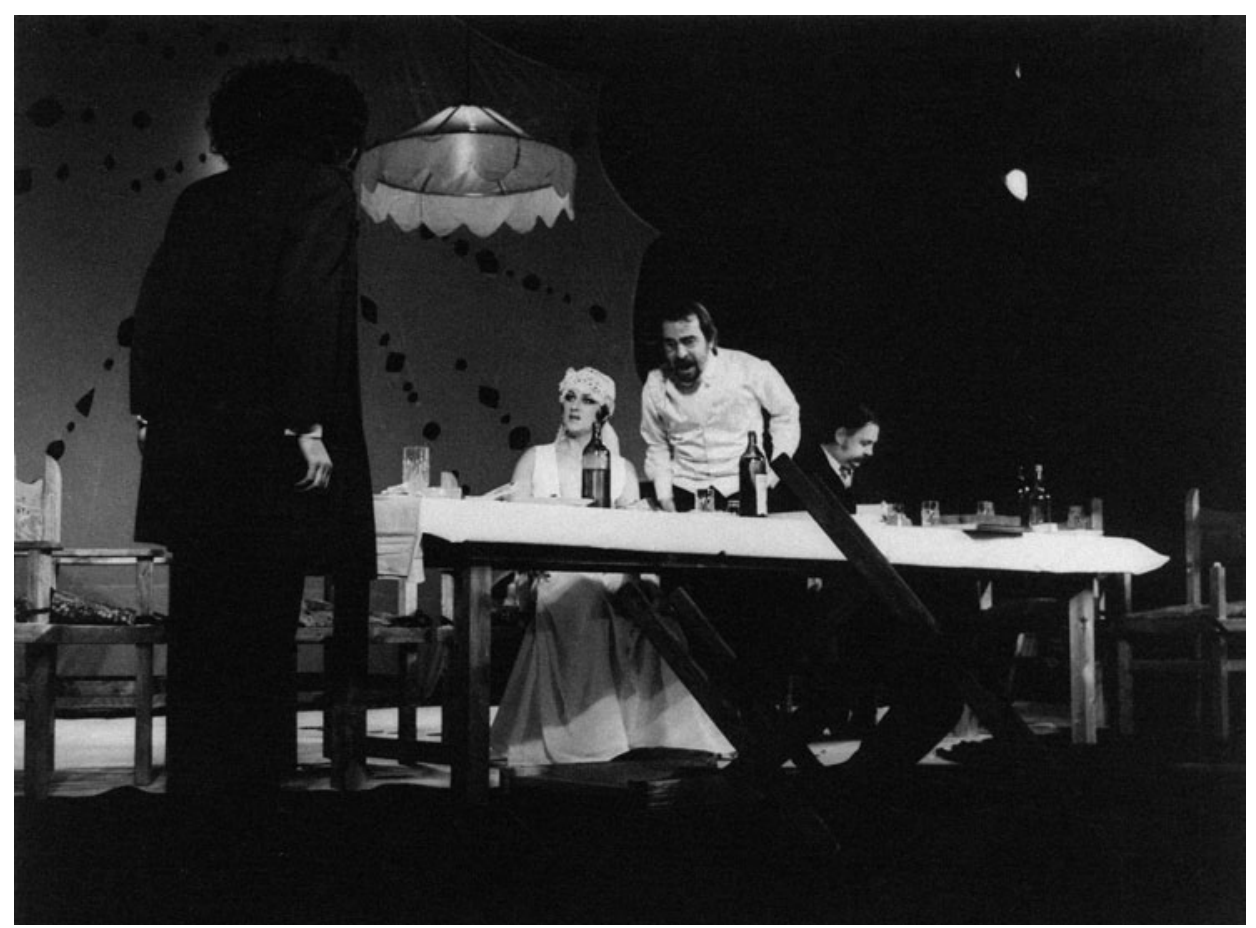

Bertolt Brecht: Malomeštiakova svadba. Krajové divadlo Nitra, premiéra 28. 1. 1978. Réžia Ivan Krajíček. Zl’ava Vladimír Bartoň (Ženíchov priatel'), Nora Kuželová (Nevesta), Marián Slovák (Ženích), Jozef Dóczy (Otec nevesty). Foto archív Divadelného ústavu Bratislava. Snímka Pavol Dřízhal.

zovaný. Herci neustále artikulovali nudu, zatial’ čo obecenstvo sa na nich dobre zabávalo. Vznešené myšlienky postáv boli paródiou ich skutočných podôb. Mechanizmus malomeštiackej existencie zobrazený $\mathrm{v}$ jeho bujarosti a plytkosti zároveň ponúkol presne to, po čom Brecht túžil: neprostoduchú zábavu a pocit trápnosti z takéhoto obrazu o stave spoločnosti.

K d’alším umeleckým výsledkom, ktoré sa pozitívne zapísali do slovenskej inscenačnej tradície, patrí aj Život Galileiho (Divadlo Slovenského národného povstania Martin, 1979) v réžii Ivana Petrovického. Po vel’mi úspešnej inscenácii tejto hry v SND (réžia Tibor Rakovský, 1956), v hlavnej úlohe s Viliamom Záborským, mal martinský súbor nel'ahkú úlohu. Zákonite muselo dôjst’ k porovnávaniu. Príbeh o významnom vedcovi, ktorý pred cirkevnou vrchnostou zaprel zo strachu svoje učenie, bol zaiste inscenačnou výzvou - tak pri interpretácii Galileiho zrady, ako aj z hladiska hereckého stvárnenia postáv.

Moderne univerzálna a prísne racionálna scéna Jozefa Cillera budila dojem pracovne. Miesta, kde sa stále čosi deje, rodia sa myšlienky, popierajú postoje, overujú stanoviská a ich správnost'. Centrálnym prvkom bol odvíjajúci sa bal papiera upevnený na železnej konštrukcii. Slúžil na zapisovanie myšlienok vedeckého tímu slávneho prírodovedca, zároveň sa využíval ako projekčná plocha, tabul'a či stôl génia. Fungoval ako škripec, ktorý sa nezatahuje, ale naopak odvíja, inokedy zase ako stena, dvere, záves, oči a uši society. 


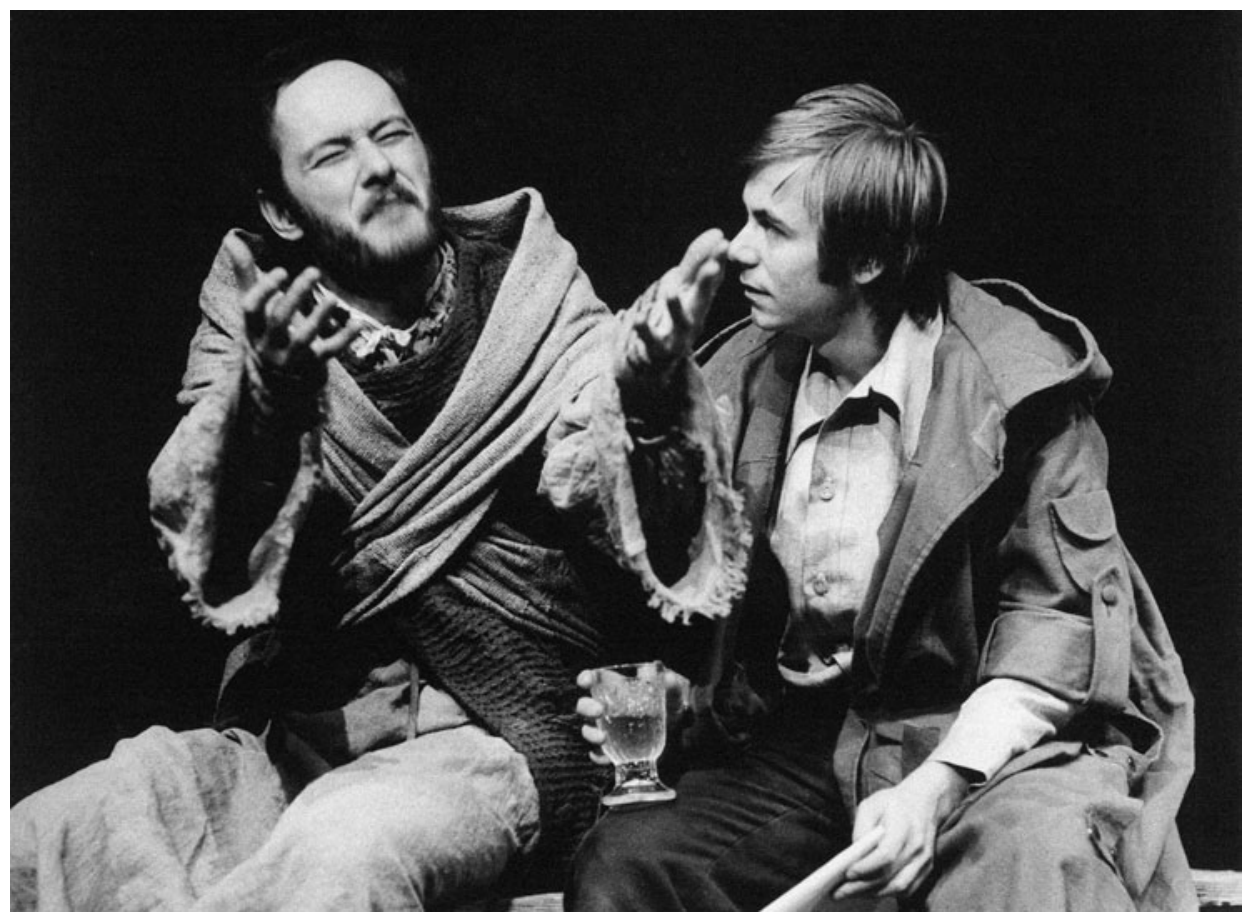

Bertolt Brecht: Život Galileiho. Divadlo Slovenského národného povstania Martin, premiéra 19. 1. 1979. Réžia Ivan Petrovický. Ivan Romančík (Galileo Galilei), Martin Horňák (Andrea Sarti). Foto archív Divadelného ústavu Bratislava. Snímka Jaroslav Barák.

Režisér mal k dispozícii mladú hereckú generáciu martinského divadla a v takom duchu sa niesla aj inscenácia. Galilei (Ivan Romančík) nebol starnúcim vedcom: „Brechtov Galilei mal väčšie životné skúsenosti a bol výraznejšou osobnost’ou ako jeho martinský predstavitel'. Napríklad Galileiho repliky sú často na úrovni filozofických právd, definícií, jasnozrivo prenikajú až k samej podstate, na scéne však akoby ubudlo z ich váhy, neznejú tak úderne. (...) Romančík svojím výkonom prispel vel'kou mierou k celkovému tónu inscenácie. Ak by sme ju charakterizovali ako vo výraze striedmu, viac zamestnávajúcu racio ako emocio diváka, komornú, tak by sme mohli adekvátne slová použit’ aj na charakterizáciu práce hlavného predstavitel'a. “37

Režisér Petrovický vytvoril inscenáciu štýlovo čistú, s originálnymi interpretáciami vztahov postáv a zároveň vzt̉ahov hercov k postavám. Upustil od väčších vášní a citových rozpoložení, viac sa zameral na racionálne poukázanie na problémy spoločnosti atómového veku. Učenec Galilei mal živelnost' svojho mladého hereckého predstavitela. Radost’ z bádania bola podrobovaná jeho kritickým otázkam. Stal sa tak tribúnom myšlienok. Bol tým, kto prostredníctvom divadla demonštruje myšlienky (dopomohli tomu Romančíkom spievané songy), kladie otázky, na ktoré musí

${ }^{37}$ MISTRÍK, M. K inscenácii hry Bertolta Brechta v Martine. Práca a život Galileiho. In Pravda, 1979, roč. 60 , č. 44 , s. 5, 21. 2. 1979. 


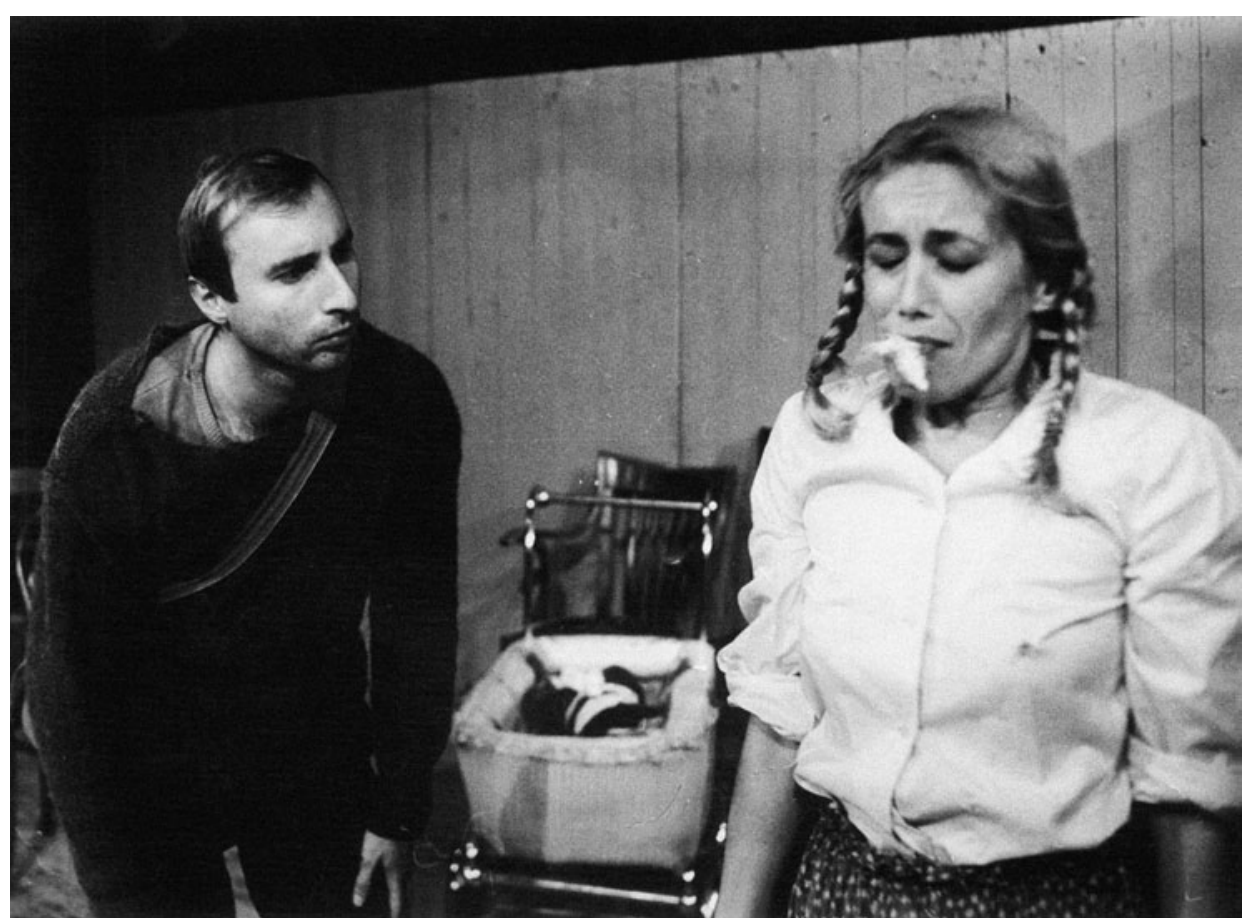

Bertolt Brecht: Kaukazský kriedový kruh. Divadlo pre deti a mládež Trnava, premiéra 24. 6. 1983. Réžia Ondrej Šulaj. Peter Šimun (Simon Chachava), Yvetta Weiszová (Gruša Vachnadze). Foto archív Divadelného ústavu Bratislava. Snímka Bohuš Král'.

odpovedat’ sám divák. Nebol morálnym vítazom ani zbabelcom, Ivan Romančík sa vyhol jednoznačnej interpretácii Galileiho zrady. Brecht hru niekol'kokrát prerábal práve s cielom, aby divák v žiadnom prípade nemal s vedcom sympatie ani zlutovanie. Jednotlivé situácie a Galileiho výstupy sa mali odohrávat prirodzene, nenápadne a spontánne. Jadrom všetkého úsilia inscenátorov malo byt’ prenesenie diskusie a protirečivosti právd starej a novej doby priamo na javisko. Galilei bol pre neho zločincom novej doby, ktorá sa nevedela bránit’ zneužitiu pravdy a vedomostí. ${ }^{38}$

Život a dielo Galilea Galileiho akoby sa v martinskej inscenácii stali procesom d’alšieho výskumu, parabolou pre náš svet - čo zradíme, ako a prečo sa zachováme. Azda v tom tkvelo jej nóvum a angažované gesto, hoci mala aj svoje sporné miesta, napr. scénu vyzliekania pápeža, vedúcu napokon k jeho zakročeniu proti Galileovi. ${ }^{39}$ Ponúkla dialektický a objektivizovaný obraz dnešného sveta, v ktorom vedci rovnako ako všetci ostatní môžu byt’ príčinou toho, že sa napokon apokalyptická vízia naplní: „(...) východiskom i objektom ich [tvorcov - pozn. E. K.] výpovede sa stalo postavenie človeka v dnešnom svete. Preň sa stalo charakteristické o. i. nebývalé zospoločenštenie vedy, uplatňovanie jej objavov v každodennej praxi, pričom rubom

${ }^{38}$ REICH, B. Bertolt Brecht, s. 115.

${ }^{39} \mathrm{~V}$ Brechtovej hre pápež pod nánosom odevu ako symbolu t’ažoby či váhy cirkevnej moci a hodnosti stráca svoj pôvodne žičlivý názor na Galileiho. 
súčasného vedecko-technického pokroku, výsledkom zneužitia humánneho poslania vedy je balans medzi rozkvetom a sebazničením. ${ }^{\text {40 }}$

S mladšou a na civilnejšom hereckom prejave stavajúcou hereckou generáciou sa v Divadle pre deti a mládež v Trnave stretol aj Ondrej Šulaj ako režisér inscenácie Kaukazský kriedový kruh (1983). Šulaj sa v tomto divadle predstavil ako tvorca, ktorý mal k brechtovskej poetike blízko už vlastným scenárom Epizóda 39-44, ktorý v roku 1978 zrežíroval Blahoslav Uhlár. Text Kaukazského kriedového kruhu výrazne pozmenil a aktualizoval. Staré čínske podobenstvo o dietati, ktoré prisúdi kriedový kruh tej z dvoch matiek, ktorá ho má skutočne rada, zmenil už sám Brecht. Zasadil ho do iných geografických i spoločenských reálií, o dietati napokon nerozhodne kruh, ale omylom, na základe l’stivej a podvodnej povahy, sudca Azdak. V Šulajovej inscenácii tvorila podobenstvo modelová parabola sporu dvoch kaukazských družstiev o pôdu. Tá mala byt’ v Brechtovej koncepcii pridelená (podobne ako diet’a) tomu družstvu, ktoré skutočne dokáže pôdu a prírodné zdroje zvel'ad'ovat' v prospech ostatných.

Šulaj posunul Kaukazský kriedový kruh bližšie k súčasnosti. Spor o pôdu sa už neodohrával medzi kolchozníkmi z obdobia Vel'kej vlasteneckej vojny ${ }^{41}$, ale na bežnej schôdzi rol’níkov a chovatel'ov dobytka. Záverečnou pointou bolo, že sa na spornej pôde postaví priemyselný kombinát, o čom rozhodne „anonymná a neinformovaná vrchnost" “42, nie tí, čo pôdu obrábajú. Preto pozmenil úvod hry, viaceré motívy, typizácie i povahy postáv, ktoré sa stali priamočiarejšie a strohejšie. ${ }^{43}$ Podobne strohá bola scéna Jána Zavarského, využívajúca niekol'ko stolov a stoličiek. Neplnili však funkciu viacvýznamovo používaných rekvizít. Proscénium od zadného javiska oddel'oval sivý latkový plot - múr: „Niet tu divadelnej ilúzie, inscenácia je strohá, aj bez scénických premien variabilná. Slúži hercovi. Spolieha sa naň. ${ }^{44}$

Šulaj obsadil do inscenácie sedemnást’ hercov, ktorí hrali viacero postáv. Tým popri vtipných hereckých akciách vznikal aj chaos na javisku, spôsobený množstvom mikroakcií. Herci, zo spoluprác s režisérom Jurajom Nvotom odchovaní na civilizme a nie precíznej štylizácii, nedokázali nájst' hranicu medzi hraním a komentovaním. Komentár prevážil, čím sa oslabil brechtovský princíp nejednoznačnosti a protirečivosti. Odzrkadlilo sa to napríklad v postave Speváka (Jaroslav Filip), ktorá naraz plnila úlohu rozprávača, komentátora, demonštrátora, režiséra javiskového diania. ${ }^{45}$ Konanie všetkých postáv (detí atómového veku) sa vyznačovalo surovostou a agresívnostou. Hrubá sila vítazila nielen nad slabším (dieta v perinke), ale aj nad spoločným záujmom. Výsledkom každého vzájomného kontaktu bola snaha ponížit toho druhého: „Z pozadia príbehu vystupujú dvaja lekári. Štefan Kožka a Ladislav Kočan. Sú to manipulátori, muži z mestského podsvetia, elegantní gangstri a gauneri. Akoby do tejto inscenácie zablúdili zo Strachu a biedy tretej ríše. Stelesňujú úzkost', násilie, šedú eminenciu, neviditel’nú ruku pomsty. ${ }^{* 46}$

\footnotetext{
${ }^{40}$ PALKOVIČ, P. Život Galileiho. In Film a divadlo, 1979, roč. 22, č. 7, s. $24-25$.

${ }^{41}$ Hra je poslednou, ktorú Brecht napísal v americkom exile.

${ }^{42}$ PORUBJAK, M. Bertolt Brecht v trnavskom divadle. Chladná uzavretost' kruhu. In Práca, 1983, roč. 38, č. 234, s. 6, 4. 10. 1983.

${ }^{43}$ F-a. Napriek výhradám záslužná inscenácia. Kaukazský kriedový kruh v Trnave. In Hlas l’udu, 1983, roč. 29, č. 156, s. [3], 5. 7. 1983.

${ }^{44}$ ČAVOJSKÝ, L. Brecht bez ilúzie. In Film a divadlo, 1984, roč. 28, č. 3, s. 16.

${ }^{45}$ Reč pritom Jaroslav Filip rytmizoval zvukom gruzínskych bubienkov a tamburíny.

${ }^{46}$ ČAVOJSKÝ, L. Brecht bez ilúzie. In Film a divadlo, s. 16.
} 


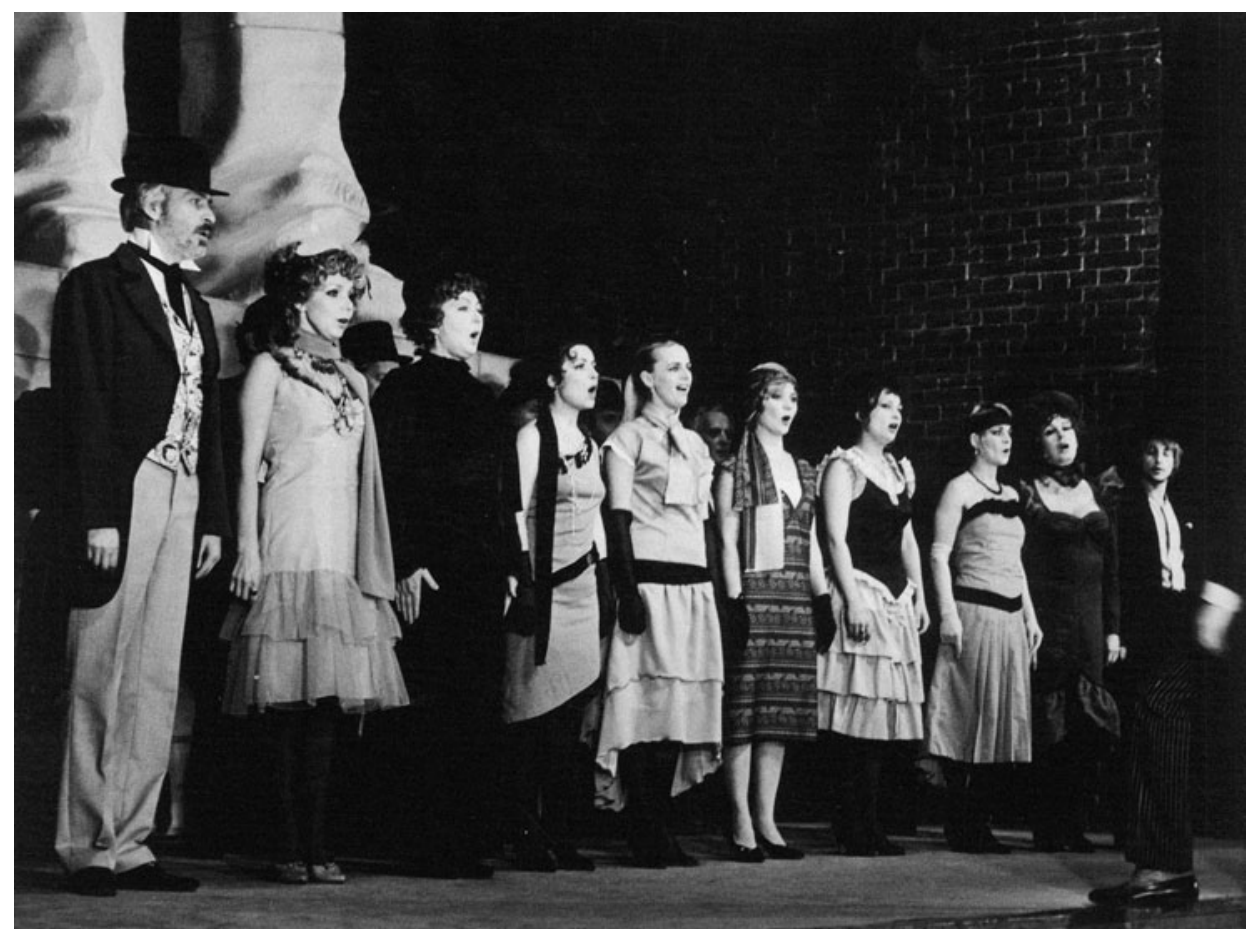

Bertolt Brecht: Žobrácka opera (Koldusopera). Mad’arské oblastné divadlo Komárno, premiéra 16. 12. 1883. Réžia Miroslav Procházka ml. Zl’ava Imre Boráros (Brown), Anna Petrécsová (Molly), Anna Ferenczyová (Jenny z putiky), Mari Vársányiová (Betty), Etela Kucmanová (Polly Peachumová), Erszébet Tóthová (Lucy), Ildikó V. Máková (Dolly), Ildikó Benesová (Vixen), Aranka Szentpéteryová (Cecília Peachumová), Tibor Fabó (Ede). Foto archív Divadelného ústavu Bratislava. Snímka Karol Belický.

Striedaním dvoch polôh, agresívnej a komentátorskej, sa inscenácia stávala monotónnou a nudnou, až v nej zanikla aj záverečná pointa, že o pôde napokon vôbec nerozhodnú tí, ktorí ju zvel'ad’ujú a obrábajú, ale z pozície moci niekto tretí. Režisér schematicky vytváral výstupy podl'a chladného pozorovania sveta, nenachádzajúc v ňom nádej ani možnost’ nápravy. Jeho racionálny pesimizmus korešpondoval s Brechtovou skeptickou interpretáciou Kaukazského kriedového kruhu, ktorá spochybňovala možnost' spravodlivého zavŕšenia podobenstva. Režisér Šulaj použil Brechta podobne, ako Brecht použil pre svoje myšlienky a postoje iných autorov. Trnavskú inscenáciu možno z tejto perspektívy považovat za poučený vstup do diskusie o modernom prístupe $\mathrm{k}$ inscenovaniu. Brecht bol vo svojej dobe humanista a pochybujúci optimista, Šulaj skeptik.

Druhý kontakt MOD Komárno s Brechtom sa udial v roku 1983 prostredníctvom na Slovensku už udomácnenej Žobráckej opery (Koldusopera) v réžii Miroslava Procházku ml. Bola to jeho prvá profesionálna réžia, ktorou sa predstavil západoslovenskému obecenstvu. Dobová kritika si všimla Procházkovu poučenost’ a inscenáciu prirovnávala k inscenácii Emila Františka Buriana v D divadle. Procházka vycítil didaktický duch brechtovského divadla, ktoré depatetizuje deje i postavy. Na viace- 


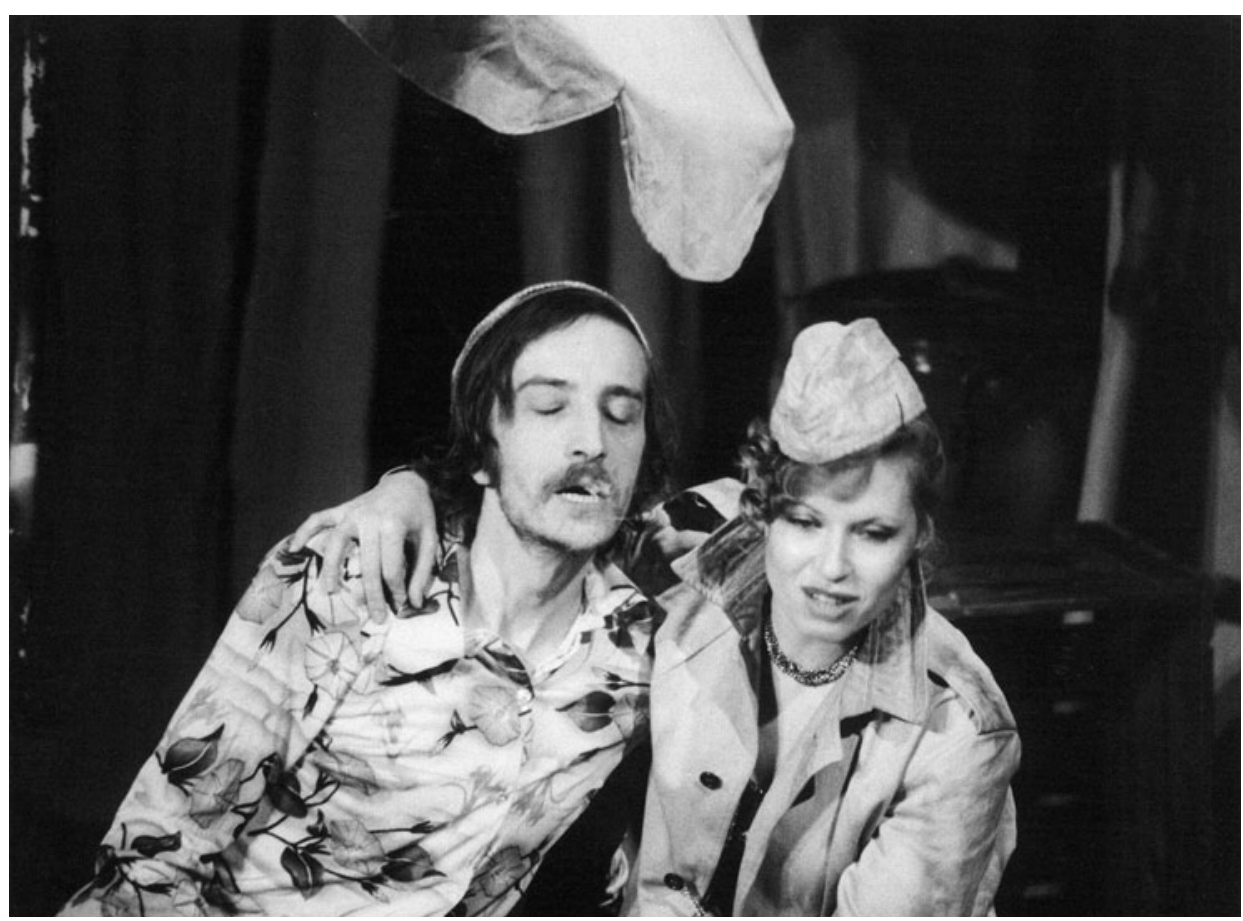

Bertolt Brecht: Muž ako muž. Divadlo pre deti a mládež Trnava, premiéra 1. 3. 1985. Réžia Juraj Nvota. Jaroslav Filip (Galy Gay), Iveta Kožková (Leokadja Begbicková). Foto archív Divadelného ústavu Bratislava. Snímka Vladimír Raiman.

rých miestach vtipne pointoval a ironizoval (napr. umiestnením štikacích hodín vo verejnom dome), zo zábavy urobil satirický nástroj angažovanosti.

Dominujúcou zložkou sa stalo výtvarné riešenie scény Tibora Platznera, ktoré nebolo len kulisou, ale nositel'om interpretácie hry: „Na rampe, horizontálne deliacej javisko na dve významové vrstvy, v miernom rozkroku je situovaný jeden pár čižiem v nadživotnej vel'kosti. “47 Čižmy - teda tí hore - akoby tlačili a dozerali na tých dolu. Tým sa hned' v úvode inscenácie ozrejmila rovnica o gangstroch a meštiakoch, s výsledkom, že všetci sú gangstri.

Hierarchizácia postáv nezodpovedala ich ustálenému výkladu. Macheath (István Holocsy) bol už len figúrkou, ktorú iní postrkujú ako v rozohranej partii šachu na postoch podsvetia. Silové pozície prebrali Vreckár Jakub (József Ropog), ktorý stojí ako tieň v pozadí všetkého diania, a Polly (Etela Kucmanová). Práve ona oznámi otcovi, vystupujúc po schodoch smerom hore, priatel'ské spojenie podsvetia so strážcami poriadku. Výmena hláv gangstrov - Macheath svoju úlohu dohrá ako muž bez hlavy - sa udeje pod pevne rozkročenými nohami „tých hore ${ }^{\prime 4}{ }^{8}$ Hoci inscenácia vykazovala nedostatky v hereckej technike a hudobno-speváckej zložke, úsilie o dodržanie brechtovského

\footnotetext{
${ }^{47}$ FERKO, T. Interné hodnotenie. In Divadelný ústav Bratislava : Zbierka inscenácií. Brecht, Bertolt. Žobrácka opera (Koldusopera), 16. 12. 1983, MOD Komárno, s. 1.

${ }^{48}$ Tamže, s. 2
} 


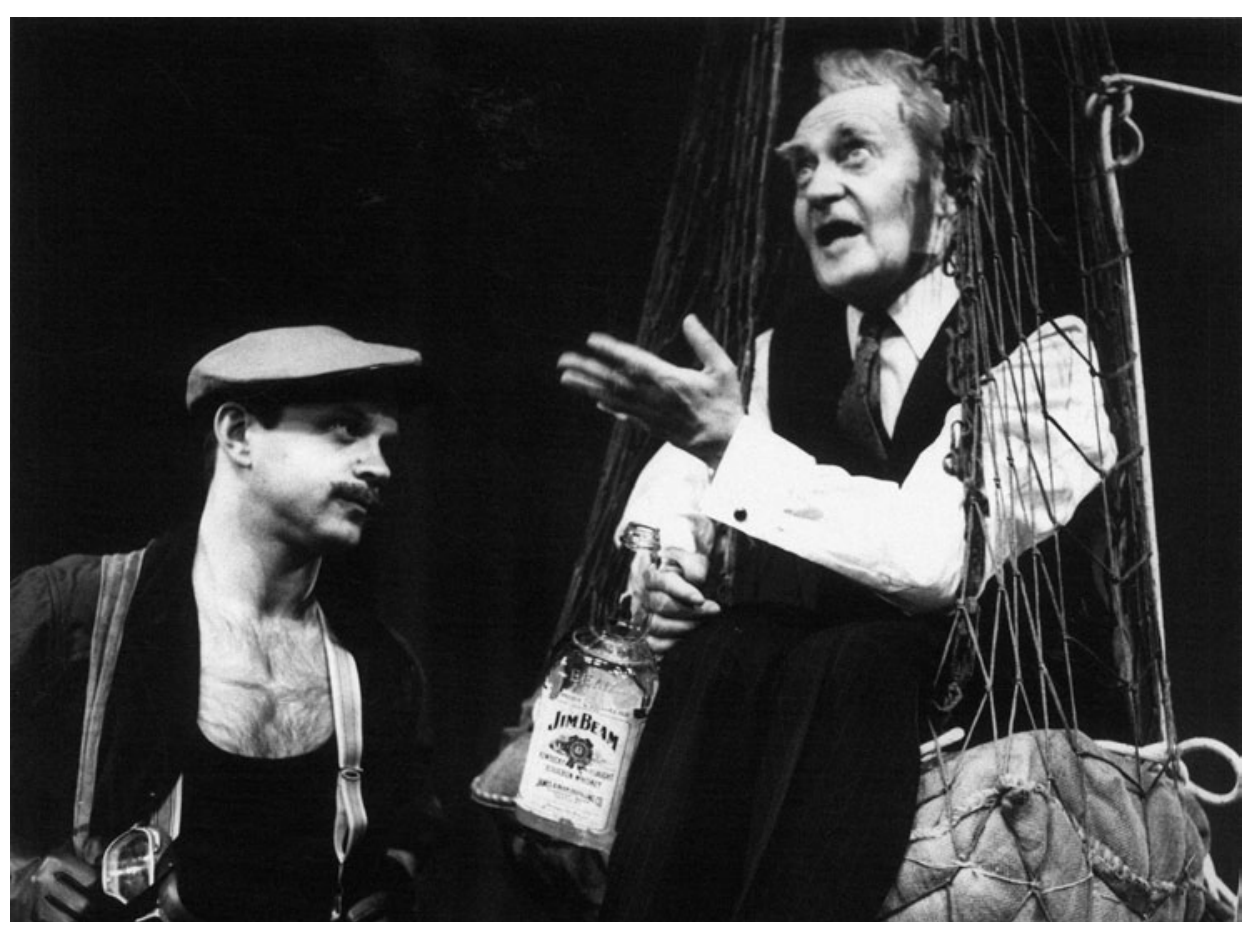

Bertolt Brecht: Pán Puntila a jeho sluha Matti. Divadlo Slovenského národného povstania Martin, premiéra 7. 5. 1985. Réžia Martin Porubjak. Peter Bzdúch (Matti), Tibor Bogdan (Puntila). Foto archív Divadelného ústavu Bratislava. Snímka Jaroslav Barák.

odstupu (odlúčenost’ slova od hudby, videného od počutého) bolo zjavné, podobne tak využitie prvkov jarmočnej l’udovej formy a satiricky deformujúcej štylizácie.

Po úspešnej inscenácii Muž ako muž na Poetickej scéne Bratislava sa rovnaký titul po desiatich rokoch inscenoval aj na javisku DPDM Trnava v réžii Juraja Nvotu (1985). Necelé dva roky predtým si súbor overil zákonitosti epického divadla pri inscenovaní Kaukazského kriedového kruhu. Kritika vtedy inscenácii vyčítala príliš nedbalú, civilnú štylizáciu, sformovanú v súbore pod vplyvom spoluprác s Jurajom Nvotom. To isté sa udialo aj v prípade inscenácie $M u z ̌$ ako muž, v ktorej súbor pod vedením režiséra Nvotu nedokázal obohatit svoj arzenál o nové výrazové polohy. Brechtovsky údernú a v podstate krutú poetiku hry ponechali len v rovine jej prvoplánovej zábavnosti, herectvo demonštrovania myšlienky ustúpilo do úzadia hravej fantázii režiséra. Kritička Soňa Šimková v tomto kontexte uvádza v internom hodnotení: „,[Herci] Sú stále mäkkí, uvol’není, v premontúvacích operáciách hraví a recesisticky šibalskí. Celá oblast’ surovosti a násilia, akoby im bola vzdialená. “49

Inscenácia sa vyznačovala vysokým tempom fyzických hereckých akcií a variabilnostou vzájomne rozohrávaných vztahov medzi postavami, čomu napomáhalo

${ }^{49}$ ŠIMKOVÁ, S. Interné hodnotenie. In Divadelný ústav Bratislava : Zbierka inscenácií. Brecht, B. Muž ako muž, 1. 3. 1985, DPDM Trnava, s. 6. 
i scénografické riešenie Jána Zavarského. Dominoval mu premenlivý a významovo variabilný vojenský stan, ktorý ako „prízrak prihrmí na javisko ${ }^{\prime 50}$ a postupne vtahuje do útrob svoje obete. Komediálna samoúčelnost', povrchne načrtnutá karikatúra so sklonom k paródii, dokonca aj pri scénach násilia a agresivity, bez ich vážnejších kritických protipólov, však nekorešpondovala s Brechtovým tvorivým zámerom ani architektonikou drámy.

Vynaliezavým riešením bolo zverenie funkcie zboru skupine zmrzačených vojakov, ktorí počas inscenácie varovali a bubnovali na bubny, čím upozorňovali na „produkty a obete“ vojenskej mašinérie. Úpravami a preorganizovaním textu (dramaturgia Mirka Čibenková) sa síce zvýraznil epický ráz predlohy, ale odstránili sa dôležité kontrastné motivácie postáv, celková útočnost’ a krutost' výpovede. Inscenátori si neporadili ani so záverom, ktorý Brecht sám menil podla potreby, a preto ho vyškrtli. Tým sa stratila záverečná pointa i filozofický rozmer hry o bezcharakternom premontovaní jednotlivca spoločnostou a jeho rovnako bezcharakternom podvolení sa mocenským silám. V prípade trnavskej inscenácie sa nezopakoval výrazný spoločenský a intelektuálny účinok, ktorý dosiahla inscenácia Poetickej scény. Potvrdilo sa, že Brechtove hry sú účinné najmä vtedy, ak prinášajú divákom pohlad na súčasné hybné sily dejín a spoločnosti, s ktorými vytvárajú dialóg.

V roku 1985 boli inscenované ešte d’alšie tri hry: Kaukazský kriedový kruh ${ }^{51}$ (Bábkové divadlo Nitra, réžia Ján Hižnay), Pán Puntila a jeho sluha Matti (DSNP Martin, réžia Martin Porubjak) a Malomeštiakova svadba (Nová scéna Bratislava, réžia Vladimír Strnisko). Popularite sa tešili najmä tie tituly z Brechtovej tvorby, ktoré umožňovali hercom a režisérom vytažit’ z nich v inscenáciách komediálny potenciál.

Takto pristupoval k hre Pán Puntila a jeho sluha Matti aj Martin Porubjak, ktorý položil dôraz na spontánny humor a poetiku l’udovej hry. Pán Puntila... je Brechtova najjednoduchšia hra, čo sa týka dialektiky vzájomných protirečení. Dramatik ňou predostrel tému nezmieritel'nosti triednych protikladov (statkári a ich sluhovia) a zároveň neudržatel’nost' takého stavu spoločnosti, kde jedni sú v područí iných, ktorí ich ovládajú a vykoristujú. Príbeh o Puntilovi, človeku dvoch tvárí, zasadil do atmosféry očarujúceho fínskeho vidieka a tomu prispôsobil reč i charaktery.

Atmosféru magického, erotikou a živelnostou nasiaknutého vidieku dodržal ako dôležitý inscenačný a výtvarný prvok aj režisér Porubjak. V súlade s Brechtovými postojmi domýšlal, prepisoval a menil predlohu podla svojho vlastného videnia sveta. Pri posúvaní jednotlivých významov, motivácií a vzt’ahov sa však dostal do kolízie s pôvodným textom a miestami aj s vlastnou interpretáciou. Sluha Matti bol v podaní Petra Bzdúcha viac dravý a frajersky drzý než jeho brechtovský predobraz. Bohorovne si sadal za stôl so svojím pánom, miestami sa zdalo, akoby bol práve on v polohe diktátora. Zo služby u Puntilu chcel vytažit čo sa dá, a to aj prostredníctvom mileneckého pomeru so statkárovou dcérou. S prehladom znášal zábavné pijanské

${ }^{50}$ JARÁBEK, M. K inscenácii Muž ako muž v trnavskom DPDM. Ďalší pokus o Brechta. In Pravda, 1985, roč. 66 , č. 75, s. 5, 29. 3. 1985.

${ }^{51}$ Pre bábkové divadlo, hoci umožňuje využit svoj antiiluzívny potenciál, bola takáto vol'ba v sedemdesiatych rokoch nanajvýš netradičná. Režisér Hižnay ju inscenoval ako rozprávku pre staršie deti a mládež od 12 rokov, bez spoločensko-politického kontextu. BD Nitra si Brechtovu hru zvolilo dokonca ako reprezentatívny titul k 40. výročiu oslobodenia krajiny, s ambíciou zúčastnit’ sa s ňou celoštátnej bábkarskej prehliadky. Recenzie boli zdrvujúce. Pozri SLIUKOVÁ, D. Interné hodnotenie. In Divadelný ústav Bratislava : Zbierka inscenácií. Brecht, B. Kaukazský kriedový kruh, 22. 3. 1985, Bábkové divadlo Nitra, s. 1. 


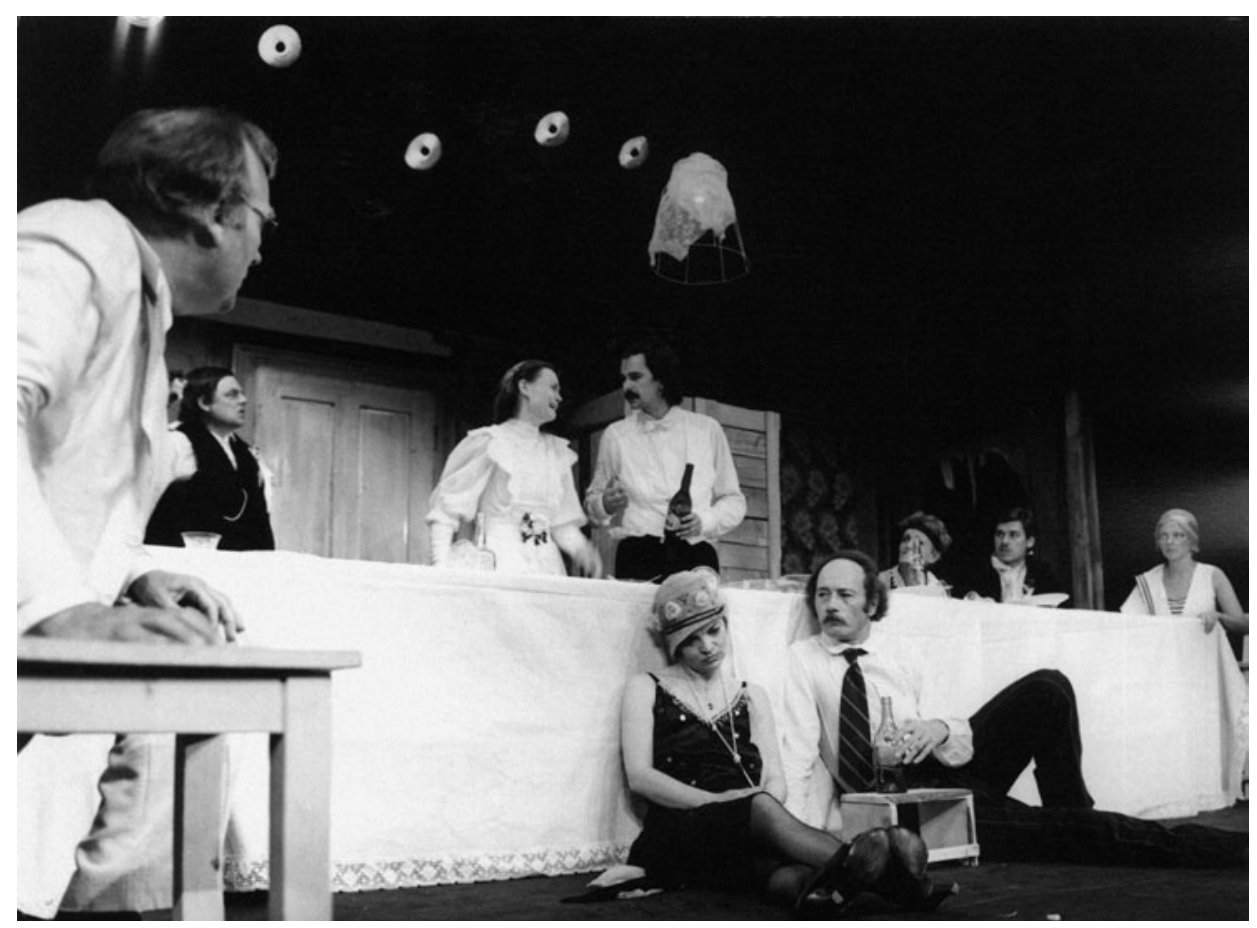

Bertolt Brecht: Malomeštiakova svadba. Divadlo Nová scéna Bratislava, premiéra 1. 6. 1985. Réžia Vladimír Strnisko. Zl’ava Ivan Letko (Manžel ženy), Stano Dančiak (Nevestin otec), Ol'ga Solárová (Nevesta), Boris Farkaš (Ženích), Ida Rapaičová (Žena), Ivan Romančík (Ženíchov priatel), Eva Rysová (Ženíchova matka), Marek Ťapák (Mladý muž), Jarmila Koleničová (Nevestina sestra). Foto archív Divadelného ústavu Bratislava. Snímka Igor Teluch.

excesy, vyznania a prajné sl’uby svojho pána, rovnako ako jeho kruté záchvaty v stave triezvosti. Avšak len do toho času, kým si neoveril, že jeho pán „sl’ubuje, ale nedáva, ani neurobí nič závažné “52. Takýto Matti by sotva mohol byt’ zhnusený z nel’udského zaobchádzania svojho pána s poddanými. Zrejme by mu ani nevadilo, že z neho Puntila urobil spoluvinníka svojho krutého konania. Naopak, vadilo by mu, že jeho pán je nekonzistentný a v opitosti má slabé chvílky milej povahy. V závere hry sa teda Matti už nelúči so svojím zamestnávatel’om a jeho triedou, ale s jeho statkom a celou krajinou ako starým svetom, ktorý mu už viac nemôže vyhovovat'.

Nami zvolenú dekádu uzatvára Strniskova inscenácia Malomeštiakovej svadby. Brecht ju napísal ako realistickú grotesku, modelový príklad demaskovania mravnej zvrhlosti malomeštiactva ako vládnucej triedy, ktorá je d’alej neudržatel'ná. Podl’a vzoru ludovej hry ju obdaril drsným humorom. Režisér žánrovo posunul hru od grotesky $\mathrm{k}$ fraške. Hoci dodržiaval strihy postáv a rozprávačskú formu v intenciách epického divadla, viac sa sústredil na komediálne herectvo vonkajškového, ukazovacieho gesta. Dochované recenzie potvrdzujú, že mu domáca kritika najviac vyčítala nedostatočný cit pre kultivovanú zábavu na úkor preexponovaných gagov, ktoré vy-

${ }^{52}$ REICH, B. Bertolt Brecht, s. 125. 


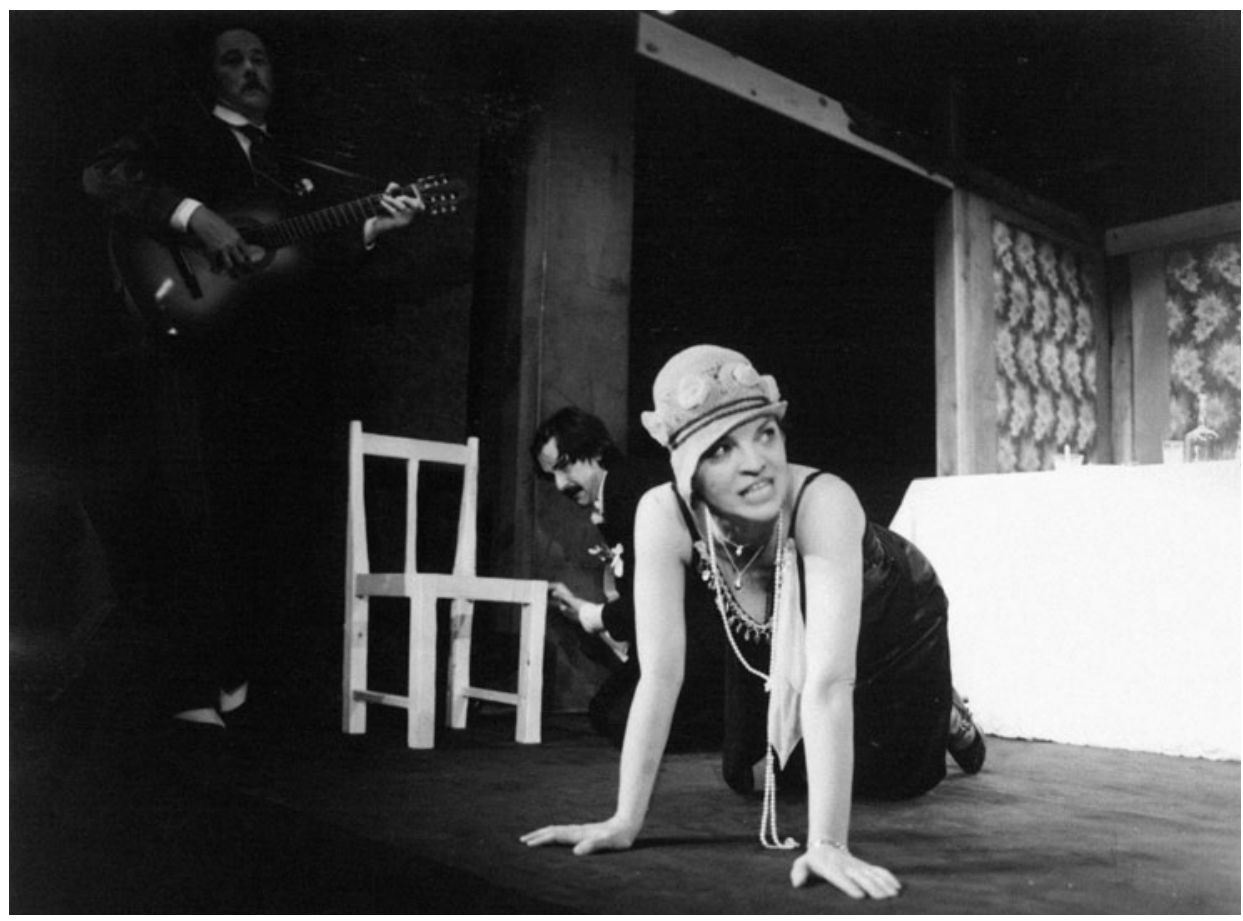

Bertolt Brecht: Malomeštiakova svadba. Divadlo Nová scéna Bratislava, premiéra 1. 6. 1985. Réžia Vladimír Strnisko. Zl'ava Ivan Romančík (Ženíchov priatel'), Boris Farkaš (Ženích), Ida Rapaičová (Žena). Foto archív Divadelného ústavu Bratislava. Snímka Igor Teluch.

znievali miestami rozpačito: „Nielen humor, ale aj dianie sa neraz pohybuje na čiare deliacej vkus od nevkusu. Krajíček v Nitre túto čiaru neprekročil. Strnisko ju prekročil a neraz. (...) Preexponovaním grotesknosti trpeli charaktery i satirické jadro hry. Úplne sa síce nestratili, no značne sa oslabili v záujme pochybného efektu. " ${ }^{\text {"53 }}$

Vladimír Strnisko v inscenácii položil akcent na pseudohodnoty a prázdnotu medzil’udských vztahohov. Na svadobnej hostine sa nerozpadával už iba nábytok, ale rúcali sa doslova celé steny interiéru, celý malomeštiacky svet. V jeho videní dnešné malomeštiacke spôsoby (nie iba trieda) už stratili aj posledné zvyšky súdnosti. L'udia zhrubli a zosuroveli. Vulgárnost’ a obscénnost’ v konaní i reči ${ }^{54}$ viac nepotrebujú ani maskovanie.

\section{Záver}

Časté inscenovanie Brechtových hier sa v sledovanom období 1975 - 1985 stalo jedným z prejavov moderného smerovania nášho divadla. Väčšinou išlo o prvé

${ }^{53}$ F-a. Málo satirická Malomeštiakova svadba. Preexponovaná grotesknost'. In Hlas l'udu, 1985, roč. 31, č. 134, s. [3], s. 6, 10. 6. 1985.

${ }^{54}$ I.R. Brechtova jednoaktovka v Štúdiu Novej scény. Drsný portrét malomeštiactva. In Práca, 1985, roč. 40 , č. 142 , s. $6,19.6 .1985$. 
stretnutia či pozvolné rozvíjanie skúsenosti s brechtovskou dramatikou a prvkami epického divadla $\mathrm{v}$ mimobratislavských divadlách, pričom sa $\mathrm{k}$ tradícii uvádzania jeho hier pridali aj divadlá národnostných menšín či dokonca bábkové divadlo. Otázne je, či možno každé prvé javiskové uvedenie Brechta v niektorom zo slovenských divadiel považovat za dramaturgický počin, za oneskorené vyrovnávanie sa s týmto typom dramatiky a inscenačných postupov v európskom kontexte, čo sa týka režijnej a hereckej práce. Inscenovanie hier tohto dramatika sprevádzali v mnohých slovenských divadlách značné interpretačné aj inscenačné problémy - skôr si prispôsobovali Brechta vlastným rezervám než by sa prispôsobili jeho špecifickým kvalitám. Ani opakované nasadenie hier na repertoár či stretnutia režisérov a hercov s týmto autorom nezaručilo výnimočnejšie výsledky. Nielen herci odchovaní na divadelných princípoch realizmu, ale aj tí, ktorí mali pod vedením mladej generácie režisérov skúsenost' s civilnejším prejavom a postupmi dekompozície, sa nedokázali úplne vyrovnat's princípmi epického divadla. Naopak, ich výkony boli svedectvom tak nevyrovnanosti súborov, ako aj oslabenej schopnosti sklbit idey Brechtových hier s jeho umeleckou metódou, hoci boli tvorcovia dostatočne poučení, poznali jeho spisy o divadle a dráme, aj inscenácie zahraničných (najmä českých) divadelníkov.

"Osvojit’ si Brechta komplexne ${ }^{\prime 55}$ sa podarilo len v niekol'kých prípadoch, ktoré však predznamenávali istú kvalitatívnu zmenu. Po úspešnejších pokusoch Ivana Petrovického v DSNP Martin, Ivana Krajíčka v Nitre, no najmä Stanislava Párnického na Poetickej scéne Bratislava sa slovenskí tvorcovia s Brechtom začali vyrovnávat aj v kontexte jeho požiadavky angažovaného, politického a spoločensky účinného divadla. Od satirických a spoločensko-kritických interpretácií hier a divadelných funkcií sa v druhej polovici osemdesiatych rokov 20. storočia objavujú inscenácie, ktoré už dokázali adresne pomenovat dobu, človeka a požiadavku nevyhnutnej politicko-sociálnej zmeny, resp. jej očakávania. Inscenácie Dobrý človek zo Sečuanu režiséra Vladimíra Strniska (SND, 1986) a Baal režiséra Romana Poláka (DSNP Martin, 1989) zachytávali pocit nielen jednej generácie, ale pocit ludí celej epochy. Prinášali nádej, že sa už blíži nevyhnutný koniec komunistických štruktúr a implikovali, že pozitívni hrdinovia nás nezaujímajú, lebo dlhé roky oslabovali našu ostražitost́. Tieto inscenácie stanovili novú požiadavku pre rozvoj inscenačnej tradície Brechtových hier na Slovensku. Bola ňou požiadavka priblížit sa prostredníctvom pravdy a obraznej sily epického divadla (niekol'ko rokov pred Nežnou revolúciou) k revolučnému divadlu spoločenskej zmeny, prihlásit’ sa k tvorcom divadla vlastnej epochy, prehovorit’ k divákom žijúcim túto epochu.

\section{BERTOLT BRECHT IN SLOVAK THEATRE BETWEEN 1975 AND 1985}

\section{Elena KNOPOVÁ}

The study focuses on the productions of Bertolt Brecht's plays in Slovak drama theatre between 1975 and 1985. It sheds light on Brecht's views and his demands made on epic theatre. The study also presents a fundamental view of his aesthetics

\footnotetext{
${ }^{55}$ PORUBJAK, M. Brecht na slovenskom profesionálnom javisku. In Slovenské divadlo, s. 221.
} 
and poetics of (dialectic) theatre and drama. Timewise, it links up with an older study by Martin Porubjak published in Slovenské divadlo (Slovak Theatre) in 1975 which focused on the 1947 - 1974 period. The authoress elaborates on another decade of the production tradition of Brecht's plays in Slovak professional theatre. She makes a point that despite an ever-growing frequency of the stagings of Brecht's plays, there are only exceptional cases when Slovak theatre professionals managed to comprehensively capture Brecht's creation, such as, for instance, in the production of Muž ako muž/A Man's a Man (directed by Stanislav Párnický, 1975), Malomeštiakova svadba/A Respectable Wedding directed by Ivan Krajíček, 1978), or Život Galileiho/The Life of Galileo (directed by Ivan Petrovický, 1979). Following entertaining, satirical, and socio-critical interpretations, so typical of the decade in question, it was not until the latter half of the 1980s, when staged productions captured the feeling of an entire (totalitarian) epoch and heralded an inevitable toppling of communist forces, while making it clear that positive heroes were no longer attractive, as they had been weakening our vigilance for many years, for instance, Dobrý človek zo Sečuanu/The Good Person of Szechwan (directed by Vladimír Strnisko, 1986) and Baal (directed by Roman Polák, 1989).

Príspevok je súčastou riešenia projektu APVV č. 15-0764 Slovenské divadlo a súčasná európska divadelná kultúra - kontinuita a diskontinuita.

\section{LITERATÚRA}

BRECHT, Bertolt. Was den Fall des Herrn Kerr betrifft... [Rukopis]. [online]. [cit. 17.3.2020]. Dostupné na internete: http://www.brecht-notizbuecher.de/content/uploads/bba-10332.058059.pdf.

BRECHT, Bertolt. Werke: Große kommentierte Berliner und Frankfurter Ausgabe, zväzok 21. (Eds. Werner Hecht at al). Berlín : Aufbau-Verlag ; Frankfurkt am Main : Suhrkamp Verlags, 1992. 835 s. ISBN 978-3-518-40070-8.

BRECHT, Bertolt. Myšlenky. Praha : Československý spisovatel, 1958. 165 s.

ČAVOJSKÝ, Ladislav. Brecht bez ilúzie. In Film a divadlo, 1984, roč. 28, č. 3, s. 16. ISSN 323-2921.

F-a. Smelé, ale nedomyslené. Dve Brechtove jednoaktovky v Komárne. In Hlas l’udu, 1977, roč. 23, č. 19, s. [3], 24. 1. 1977. [bez ISSN].

F-a. Dramaturgický objav - režijný čin - herecký koncert. In Hlas l’udu, 1978, roč. 24, č. 30, s. [4], 4. 2. 1978. [bez ISSN].

F-a. Napriek výhradám záslužná inscenácia. Kaukazský kriedový kruh v Trnave. In Hlas l'udu, 1983, roč. 29, č. 156, s. [3], 5. 7. 1983. [bez ISSN].

F-a. Málo satirická Malomeštiakova svadba. Preexponovaná grotesknost'. In Hlas l'udu, 1985, roč. 31, č. 134, s. [3], 10. 6. 1985. [bez ISSN].

FERKO, Tibor. Interné hodnotenie. In Divadelný ústav Bratislava : Zbierka inscenácií. Brecht, Bertolt. Žobrácka opera (Koldusopera), 16. 12. 1983, MOD Komárno. 3 s.

HECHT, Werner. Blick auf Brecht nach vorn. In Theater der Zeit, 1983, roč. 37, č. 2 , s. 7 -12. ISSN 0040-5418.

I.R. Brechtova jednoaktovka v Štúdiu Novej scény. Drsný portrét malomeštiactva. In Práca, 1985, roč. 40, č. 142, s. 6, 19. 6. 1985. ISSN 0231-6277.

JARÁBEK, Mikuláš. K inscenácii Muž ako muž v trnavskom DPDM. Ďalší pokus o Brechta. In Pravda, 1985, roč. 66, č. 75, s. 5, 29. 3. 1985. ISSN 0231-6528. 
LENYA-WEILL, Lotte. Das waren Zeitem. In Bertolt Brechts Dreigroschenbuch. 1. zväzok. (Ed. Sigfried Unsel). Frankfurt am Main : Shurkamp Verlag, 1960. 335 s. ISBN 3-518-06587-4.

MAČUGOVÁ, Gizela. Interné hodnotenie. In Divadelný ústav Bratislava : Zbierka inscenácií. Brecht, Bertolt. Pušky pani Carrarovej; Sofoklova Antigona, 14. 1. 1977, MOD Komárno. 2 s.

MISTRÍK, Miloš. Žobrácka opera ako opereta? In Pravda, 1975, roč. 56, č. 135, s. 5, 11. 6. 1975. ISSN 0231-6528.

MISTRÍK, Miloš. Brechtov návrat. In Pravda, 1975, roč. 56, č. 60, s. 4, 12. 3. 1975. ISSN 0231-6528.

MISTRÍK, Miloš. K inscenácii hry Bertolta Brechta v Martine. Práca a život Galileiho. In Pravda, 1979, roč. 60, č. 44, s. 5, 21. 2. 1979. ISSN 0231-6528.

NAVARA, Andrej. Dva pohl'ady na jedného muža. In Film a divadlo, 1975, roč. 19, č. 16, s. 24 - 25. ISSN 0323-2921.

PALKOVIČ, Pavol. Život Galileiho. In Film a divadlo, 1979, roč. 23, č. 7, s. 24 - 26. ISSN 0323-2921.

PORUBJAK, Martin. Brecht na slovenskom profesionálnom javisku. In Slovenské divadlo, 1975, roč. 23, č. 2, s. $192-223$. ISSN 0037-699X.

PORUBJAK, Martin. Bertolt Brecht v trnavskom divadle. Chladná uzavretost' kruhu. In Práca, 1983, roč. 38, č. 234, s. 6, 4. 10. 1983. ISSN 0231-6277.

REICH, Bernhard. Bertolt Brecht. Praha : Orbis, 1974. 276 s.

SLIUKOVÁ, Dana. Interné hodnotenie. In Divadelný ústav Bratislava : Zbierka inscenácií. Brecht, Bertolt. Kaukazský kriedový kruh, 22. 3. 1985, Bábkové divadlo Nitra. 2 s.

ŠÁRIK, L’ubomír. Muž ako muž. In Film a divadlo, 1977, roč. 21, č. 7, s. 24 - 25. ISSN 0323-2921.

ŠIMKOVÁ, Soňa. Interné hodnotenie. In Divadelný ústav Bratislava : Zbierka inscenácií. Brecht, Bertolt. Muž ako muž, 1. 3. 1985, DPDM Trnava. 11 s.

ŠTÚROVÁ, Nelly. Interné hodnotenie. In Divadelný ústav Bratislava : Zbierka inscenácií. Brecht, Bertolt. Žobrácka opera, 24. 5. 1975, ŠD Košice. 3 s.

VRBKA, Stanislav. Interné hodnotenie. In Divadelný ústav Bratislava : Zbierka inscenácií. Brecht, Bertolt. Malomeštiakova svadba, 28. 1. 1978, Krajové divadlo Nitra. 3 s.

Elena Knopová

Ústav divadelnej a filmovej vedy CVU SAV

Dúbravská cesta 9

84104 Bratislava

e-mail: elena.knopova@savba.sk 